\title{
シアトルに拈ける日系人コミュニティの空間的展開と エスニック・テリトリーの変容
}

杉 浦

直

I.はじめに

(1) 目的と問題の所在

(2) 用語と概念規定

(3) 調查と資料

II. シアトルにおける日系人コミュニティ の空間的展開

(1) 居住の展開と人口分布の変化
（2）日系営業施設の展開とエスニック・ ビジネスの変容

（3）エスニック共同組織の発達とコミュ ニティ施設の展開

III. 結び一日系エスニック・テリトリーの

構造とその変容一

キーワード：日系人，エスニック・テリトリー，日本人町，エスニック・ビジネス， エスニック組織, シアトル

I. はじめに

(1)目的と問題の所在 本研究は, アメリカ 合衆国西海岸の一都市，シアトルにおける日系 ペコミュニティの空間的展開及びその居住・活 動空間の構造とその変化を検討し，それを通し て北アメリカの都市における移民エスニック集 団の空間的な存り方とその領域（エスニック・ テリトリー）の変容過程を考察しょうとしたも のである。

移民エスニック集団は，母国の文化一社会的 状況を背景としつつも, そこから切り離され異 国の特定の地域に参入 ·定着し, 新しい環境的 一文化的状況に適応・統合する過程において, その集団的性格を变化させる。その過程は，母
国とは異質のホスト社会のシステムの中におけ るある程度自立的な内的結合をもったサブシス テムの変容過程，すなわちエスニシティの変容 過程，としてとらえられる。移民エスニック集 団とそのエスニシティの変容は，これまで様々 な人文・社会諸科学の対象となってきたが，地 理学においてはそれらの成果を踏まえつつ, 空 間的視点を導入して，エスニシティの空間的在 り方と空間的変容過程をとらえ直していくこと が求められる。

移民エスニック集団，あるいはエスニシティ， に関するこれまでの地理学的研究は, 広域的な 集団の人口分布や地理的領域確定の分野を除け ば，農村地域（非都市地域）と都市地域という 2 つの異なる地理的場の文脈における研究カテ

1）ここでは, 戦前から現在までの「アメリカ合衆国における日本人移民とその子棌」の総称として, 便宜的に「日系人」 の語を用いる。

2) Allen, J. P. and E. J. Turner, We the People: An Atlas of America's Ethnic Diversity, Macmillan, 1988, 315p. が, そ の一つの集大成である。 
ゴリーに大別される。そのうち，農村地域にお けるエスニック集団の地理学的研究においては, 諸集団の植民過程や土地への適応過程，その結 果成立したエスニックな特色をもつ農業的土地 利用システムや農業慣行, 特定の農業形態と移 民集団との結びつき（エスニック産業としての農 業)，移民集団が地表に刻印したエスニックな 文化景観，特に土地区画，集落パターン，住居 やバーン (馬房) の形態，など多様な事象・テ 一マが扱われてきたが，概ねそれらは文化地理 学, 集落地理学, 農業地理学などにおける伝統 的な関心からのものであったと言える。それに 対して，都市地域におけるエスニック集団の地 理学的研究は，特に諸集団のすみわけとその結 果としてのエスニック集住地区（ゲットー）の 形成など特定の問題に集中しがちであった。

そのうち，都市地域内部における諸エスニッ ク集団の “すみわけ（residential segregation）” の現象に関しては，小地域統計を用いたそのパ ターンの確認が地理学者によって繰り返し行な われてきだ。た，1つのエスニック集団と全
体人口あるいはエスニック集団間の“すみわ け”を計量的に測定する方法の開発や，諸エス ニック集団間の居住の空間的相関あるいは混合 ・分離の考察なども試みられてきた。しかしな がら，この分野の研究においては，空間的パ夕 ーンそれ自体に焦点があてられ，その枠内で分 析方法のみ精徵化していった傾向は否定できな w。

それに対して，こうした“すみわけ”を引き 起こし，都市内にエスニックな特性を帯びた空 間を出現させていく過程，すなわちその集団に とって自らの領域（エスニック・テリトリー）を 生産していく過程，あるいはそれによって成立 した領域の構造や性質，は本研究の文脈にとっ てより重要であり，本稿との関連で言及すべき 論文は多い。その中で，ワード（Ward, David） は，ボストンを例にとり，19世紀から20世紀初 頭にかけてのアメリカの都市の居住構造の中で 移民の居住地区（ゲットー）がどのように形成 されたのかを検討し，ざらに，エスニックな領 域の形成とその性格は労働のエスニックな分割

3）例えば, Stewart, N. R., 'Foreign Agricultural Colonization as a Study in Cultural Geography', Professional Geographer 15-5, 1963, pp. 1-5.

4) Cozzens, A. B., 'Conservation in German Settlements of the Missouri Ozarks', Geographical Review 33, 1943, pp. 286-298, Tower, J. A. and W. Wolf, 'Ethnic Groups in Cullman County, Alabama', Geographical Review 33, 1943, pp. 276-285, Lemon, J. T., 'The Agricultural Practices of National Groups in Eighteenth-Century Southeastern Pennsylvania', Geographical Review 56, 1966, pp. 467-496,など。

5) Sas, A., 'Dutch Concentrations in Rural Southwestern Ontario during the Postwar Decade', Annals of the Association of American Geographers (以下 A. A. A. G.) 48, 1958, pp. 185-194, Jakle, J. A. and J. O. Wheeler, 'The Changing Residential Structure of the Dutch Population in Kalamazoo, Michigan', A. A. A. G. 59, 1969, pp. 441-460,など。

6) Kniffen, F., 'Folk Housing: Key to Diffusion', A. A. A. G. 55, 1965, pp. 549-577, Wright, M., 'The Antecedents of the Double-Pen House Type', A. A. A. G. 48, 1958, pp. 109-117, Wonders, W. C., 'Log Dwelling in Canadian Folk Architecture', A. A. A. G. 69, 1979, pp. 187-207, Jordan, T. G., 'Alpine, Alemannic and American Log Architecture', $A$. A. A. G. 70, 1980, pp. 154-180, Jordan, T. G. with J. L. Bean, Jr. and W. M. Holmes, Texas, Westview, 1984, pp. 185-207 (Chap. 9 : Rural Settlement Geography)など。

7）例えば, Dalton, M. and J. M. Seamon, 'The Distribution of New Commonwealth Immigrants in the London Borough of Ealing, 1961-66, Trans. Inst. British Geographers 58, 1973, pp. 21-39, Matwijiw, P., 'Ethnicity and Urban Residence: Winnipeg, 1941-71, Canadian Geographer 23, 1979, pp. 45-61, Carter, J. and T. Jones, 'Ethnic Residential Space: The Case of Asians in Bradford, Tijdschrift voor Econ. en Soc. Geografie 70, 1979, pp. 86-97,など。なお，この分野の研究 例に関しては，山下や阿部の詳しい展望がある。山下清海「民族集団のすみわけに関する都市社会地理学的研究の展望」, 人文地理 $36,1984,312$-326頁, 阿部 隆「カナダ, トロント市における民族的居住分化とその混合構造」, 宮城学院女 子大学生活科学研究所研究報告 22,1990, pp. 42-58.

8）“すみわけ”の計量的測定方法は，ダンカン（Duncan, O. D.）らやトイバー（Taeuber, K.）など，まず社会学の分野 で開発・使用されたが，地理学的研究においても様々に適用・修正され用いられている。前揭 7 ) Carter and Jones, 二 神＼cjkstart弘「アメリカ都市における黒人差別の空間的アプローチ」，東北地理25，1973，pp. 1-9，など。

9) Izaki, Y., 'The Residential Correspondence between Japanese and Other Ethnic Groups in San Francisco, Geogr. Review of Japan (地理学評論)，54，1981，'pp.115-126，阿部 隆（前掲 7 ）など。

10) Ward, D., 'The Emergence of Central Immigrant Ghettoes in American Cities: 1840-1920, A. A. A. G. 58, 1968, pp. 343-359. 
の固定性および流動性，集団の労働市場との関 わり方によって規定されることを論じた。また， モリル (Morril, Richard L.) は, アメリカの都 市における「黒人ゲットー」の形成と維持の要 因を考察し，その拡大のプロセスのメカニズム をシアトルをフィールドとしたシミュレーショ ン・モデルの構築を通して解明した。イギリス では, ジョーンズ (Jones, Philip N.) がバーミ ンガムにおける「有色少数民族（colored minorities)」の集中地区の成立を住宅市場, 住宅政策 や都市計画との関係から考察した。また，移民 一世世代によって示された居住集中傾向とそれ によって形成されたエスニック・ゲットーが, 二世・三世と世代を経るにつれ解体されていく 過程, あるいはそれとエスニック集団の同化 (assimilation) との関係については，ジェーク ルとウィーラー (Jakle, John A. and James O. Wheeler) のミシガン州カラマズー（Kalamazoo）におけるオランダ人移民集団の研究や, ビゲロー (Bigelow, Bruce) のシラキュースにお けるポーランド系カソリックの居住パターンに ついての検討などが挙げられる。

こうした実証研究と並行して, ジョーダンと ロウントリー（Jordan, Terry G. and Lester Rowntree）は，都市のエスニック地区を居住に強制 力が働いているゲットーと自由意志によるネイ バーフッド (neighborhood) に分類した。さら にアメリカの都市を念頭に，都市のエスニック 地区をコアー (core), 中間域 (middle), 縁辺 域 (fringe), 郊外クラスター (outlying cluster) の 4 つに分け, 移民集団のメンバーの経済的地 位の上昇につれ，その居住域が原居住地区であ
るコアー（ゲットー）から郊外方向へ離れてい くことを論じた。こうした彼等の整理は，アメ リカの都市の移民エスニック集団の居住地区の 構造を一般化した数少ない記述モデルとして評 価できる。しかし，このモデルは集団メンバー の居住と経済的余裕の関係のみから構築された ものであり，集団の労働市場における分節や多 様な社会的・経済的活動を視野に入れていない。 そのため，エスニック・ゲットーの性質を固定 的かつ否定的に描き過ぎてしまい，エスニック ・テリトリー自体のダイナミックな発展や変容 が浮び上ってこなくなる。この点, ワードは移 民エスニック集団が初期の移動労働者 (labor migrants）の社会から労働の分割やエスニック ・インスティテューションの発達によって移民 社会へと変化すること, そしてその転換の早さ は集団や都市によって異なることに着目したが, その動きがエスニック・テリトリーの空間構造 にどう反映していくかという点についてははっ きり述べていない。しかも，多くのエスニック 集団にとって必然的な動きである自らのビジネ ス活動を確立していく過程が，ゲットーの構造 や性格をどう変えていくのかという点にも触れ ておらず, ジョーダンらと同様, 移民階梯 （immigrant's ladder）と郊外化を結びつける“工 レベーター・モデル”の段階からは十分に脱却 していないと言える。

しかし，エスニック・ビジネスの発達やエス ニックな社会的組織化の動きは，エスニック集 団に社会的なリーダーシップや構造化をもたら すのみならず，エスニック・テリトリーにもあ る種の求心性を与え, その中心部の活性化など

11) Ward, D., 'The Ethnic Ghetto in the United States: Past and Present', Trans. Inst. British Geographers (New Series) 7, 1982, pp. 257-275.

12) Morril, R. L., 'The Negro Ghetto : Problems and Alternatives, Geographical Review 55, 1965, pp. 339-361.

13) Jones, P. N., 'Colored Minorities in Birmingham, England', A. A. A. G. 66, 1976, pp. 89-103.

14）前掲 5 ) Jakle and Wheeler, および Bigelow, B., 'Marital Assimilation of Polish-Catholic Americans : A Case Study in Syracuse, N. Y., 1940-1970, Professional Geographer 32, 1980, pp. 431-438.

15) 以上, Jordan, T. G. and L. Rowntree, The Human Mosaic: The Thematic Introduction to Cultural Geography (4th ed.), Harper \& Row, 1986 (初版, 1976), Chap. 9 : Ethnic Geography (pp. 271-304).

16）前掲11), 参照。 
その構造や性質を変えていく働きがあることは 当然予想される。近年，エスニック・ゲットー のあまりにもネガティブなとらえ方への反省が 一部に見られるが，ここにもエスニック・ビジ ネスの展開やエスニックな組織化と絡めた視点 が必要とされよう。

以上に鑑み, 本研究ではシアトルの日系人コ ミュニティの空間的展開とそのエスニック・テ リトリーの変容を検討するにあたって，狭い意 味での居住パターンの他に，エスニック・ビジ ネスの空間的展開とエスニックな組織・団体の 施設 (コミュニティ施設) の立地動向を重要な指 標として採用し，それら相互の関係からエスニ ック・テリトリーの構造とそのダイナミックな 変容をとらえることを試みた。

ここで，北アメリカにおける日系人集団につ いての地理学的研究を振り返ってみると, 農業 や農村地域における日系人に関してはかなりの 成果が集積されてきたと言えるが，都市におけ る日系人の地理学的研究はあまり多くなく, 寊 聞の限り，ロサンゼルス地区を扱ったニシ (Nishi, Midori) やワレン（Warren, William Hal-

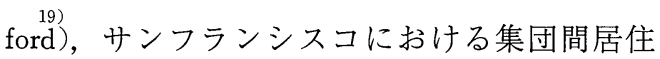
相関を分析した Izaki (井崎義治)，シアトル大
都市圏における居住分布を検討した阿部，また シアトルのアジア人街の現状を報告した阿部・ 實・杉浦，など若干例を挙げ得るに過ぎない。 本稿は, 上記シアトルにおける先行研究を受け つつ，当該都市における日系人のエスニック・ テリトリーの形成・変容過程とその性格の解明 に，より総合的に取り組もうとする試みでもあ る。

(2)用語と概念規定 本研究においては, 日 系人集団を「移民エスニック集団」として扱う。 ここで「エスニック集団 (ethnic group)」とは, より大きな社会（典型的には近・現代の国民社会） の枠組の中のより小さな (下位の) 集団, 他と 区別できる住民集団，のことである。移民とい うプロセスによってあるナショナル・ソサイエ ティの中のサブシステムとして生成した住民集 団が移民エスニック集団である。エスニック集 団のあり方, それがもっている性格・性質, 工 スニック集団としての特質や結合を保っている 状態，を「エスニシティ (ethnicity)」というう。

このエスニック集団が一定の地理的空間の中 に展開してつくる地域社会がエスニック・コミ ュニティであり，日系人集団は都市や農村など 様々な地域に扔いて「日系人コミュニティ」を

17）前掲11）やFord, L. and E. Griffin, 'The Ghettoization of Paradise', Geographical Review 60, 1979, pp. 140-158.

18）杉浦 直「インペリアル平原の日系人一地域的展開と移民地域社会の性格一」, アルテス・リベラレス（岩手大学人文 社会科学部紀要） 49,1991 , pp. 1-35, 参照。

19) Nishi, M., 'Changing Occupance of the Japanese in Los Angeles County, 1940-1950', Doctoral Dissertation, Univ. of Washington, 1955, 207p. (MS.), Nishi, M., 'Japanese Settlement in the Los Angeles Area', Yearbook of the Assoc. of Pacific Coast Geographers 20, 1958, pp. 35-48, Warren, W. H., 'Asian Populations in Los Angeles County: A Focus on the Development of Japanese Community from a Cartographic and Landscape Perspective', MA Thesis, UCLA, 1985, 195p.

20）前揭 9 )。

21）阿部 隆「アメリカ合衆国におけるアジア系住民の居住分布一ワシントン州シアトル大都市園を中心に一」, 宮城学院 女子大学研究論文集 $73,1991, p p .53-84$.

22）阿部 隆・實 清隆・杉浦 直「民族が共存するシアトルのアジア人街」, 地理36- 5, 1991, pp. 35-40.

23）綾部恒雄「エスニシティの概念と定義」，文化人類学 $1-2,1985$, pp. 8-19, 参照。

24）ここでは，小倉に従い，「移民」現象を「国境を超えて生業の本拠地を移動させる」現象としてとらえ，出稼ぎ，難民， 奴隷としての移入なども含む概念として広くとらえる。小倉充夫「移民・移動の国際社会学」（梶田孝道編『国際社会学 一国家を超える現象をどうとらえるか一』，名古屋大学出版会，1992），40一61頁。

25) Glazer, N. and D. P. Moynihan (ed.), Ethnicity: theory and Experience, Harvard Univ. Pr., 1975, pp. 1-26 (Introduction).

26）前掲15)。

27）エスニシティ概念については拙稿でやや詳しく論じたので参照されたい。杉浦 直「エスニシティ概念と文化・社会地 理学」地理38一- 9, 1993, pp. 91-97. 
形成してきた。エスニック・コミュニティは, 成員間に社会的結合関係と共同組織が発達し, 社会的リーダーシップが確立している点におい て, 単なる出稼ぎ者 ·移動労働者 (labor migrants）の集団とは異なる。

エスニック・コミュニティが展開し，そこで 生活・活動している地理的空間は，これまで農 村部では ethnic province, ethnic island, 都市 部では ghetto (ethnic ghetto, immigrant ghetto, black ghetto), ethnic neighborhood, ethnic quarter, colored cluster など様々な用語で呼ば れてきたが，本稿ではこれらを包括し得る概念 として「エスニック・テリトリー」という言葉 を用いたい。1つのエスニック・テリトリーは， 特定のエスニック・コミュニティが居住し，そ こで生活と行動を展開している生活空間，すな わち領域としての空間である。都市のエスニッ ク・テリトリーに関連して，従来当該エスニッ ク集団またはその母国の名を冠したチャイナタ ウン, イタリアン・タウン,「日本人町」(ジャ パンタウン）などの言葉が，はっきりした定義 をもたずに頻繁に使われてきた。本稿では，都 市のエスニック・テリトリーのなかで，特に当 該集団の集中居住域であり，かつその集団の営 業施設およびコミュニティ施設の集中の見られ る地区を「エスニック・タウン」と称すること にする。「日本人町」は日系人が形成し，そこ で活動しているエスニック・タウンである。

( 3 )調査と資料 本研究の主要な資料は, 主 として現地研究滞在時に得た文書・文献資料で
ある。資料の検索・収集にあたっては, 各種図 書館・文書館などの公的機関の他，日系各組織 ・団体および個人所蔵の資料もできる限り渉猟 した。

収集した文書・文献資料は多種にわたるが, 本稿の分析の最も中心的な資料となったのは日 系人住所録類である。各住所録類には, 個人名 の他に，原則として業種・種類別に分類された 日系営業施設および組織・団体の名称と住所の 記載があり, それらの数, 構成, 分布パターン の把握が可能である。本研究では収集した住所 録類から，年次の間隔と記載状況の適否を考慮 して，第 2 次大戦前については『北米年鑑（付 録住所録)』1916年版，1928年版，1936年版，戦 後については『全米日系人住所録』1949年版, $\mathrm{JACL}$ 発行の日系人住所録 1967 年, 1973 年, 1983年，1991年，計 8 年次のものを分析した。

II. シアトルにおける日系人コミュニティの空 間的展開

ここでは，シアトル(シアトル市ないしシアト ル大都市地域）における日系人コミュニティの 空間的展開過程を，1）日系人の居住展開と日 系人人口分布の変化，2）日系営業施設の展開 とエスニック・ビジネスの変容，3）エスニッ ク共同組織の発達とコミュニテイ施設の展開, の 3 つの側面に着目して，分析・検討する。な お，記述にあたっては，日系人の展開過程を便 宜的に, 第 1 期（ 1907年）：フロンティア期, 第 2 期 $(1907 \sim 1930)$ : 定住期，第 3 期（1930～

28）前掲18), 参照。

29） 1989年 9 ～10月，1991年 $7 \sim 8$ 月，1993年 4 月，同年 8 月の計 4 回。このうち，最初と最後は，文部省科学研究費国際 学術研究 (代表 : 高津斌彰) による共同調査である。

30) Japanese American Citizen's League.

31）ここで最大の問題となるのは, こうした住所録類の信頼度と対象の包括度 (カバー率) であるが, これについて厳密に 論ずることはきわめて難しい。ただ，より正確な資料と思われる合衆国議会下院移民・市民権委員会の公聴会に提出され た1920年のシアトル市における日系人経営のビジネス・リストから，住所録類とほぼ同様なビジネスの範囲を想定して比 較した場合, 戦前時についてはほぼ 7 割のカバー率は期待できるものと考えたい(資料間の年次やビジネスの分類が 異なるので，厳密な比較は困難である)。なお，本研究では，なるべく同性質の資料によって通時的変化を見たいので 「公聴会」の資料は，直接には使用しない。U. S. House, Congress, Committee on Immigration and Naturalization, Japanese Immigration Hearings before the Committee on Immigration and Naturalization, House of Representatives, 66th Congress, Washington Government Printing Office, 1921 (Arno Press, 1978, pp. 1109-1122). 
1942) : 閉塞期，第 4 期（1945 1955): 回復期, 第 5 期 $(1955 \sim)$ : 変容期, の 5 期（第 2 次大戦中の 中断期を除く）に区分した。

\section{(1)居住の展開と人口分布の変化 シアトル} の日系人人口分布に関しては，すでにミヤモト (Miyamoto, Frank, S.), シュミッド (Schmid, Calvin F.) 他, レオネッティ (Leonetti, Donna L.)，阿部などによる様々な時期（1920～80年代） についての地図化を伴った研究が為されている ので，ここではそれらの成果を比較・利用しつ つ，他の情報と総合して検討する。

1) 第 1 期 ( 1907)

シアトルにおいて，日系人がある程度集団的 に居住し始めたのは1880年代に入ってからと考 えられる。合衆国センサスの示す日系人 (Japanese）数は1890年に127人（キング郡の数字）, 1900 年にはシアトル市内で 2,990 人を数えるに 至った。

この時期における日系人の居住分布について は資料に基づいて地図化した研究がないので, 正確なパターンはつかめない。しかし，ミヤモ トによれば，初期の日本人の多くは，後の日本 人町より 4 〜 5 ブロック海岸寄りのいわゆる “スキッドロード (Skidroad)” 地区に居住して いたという（以下，第 1 図参照）。なお，この地 区のすぐ東側あたりは中国人も多く居住してい
た。当時 (1890年代) のシアトルの主要市街地 はエリオット湾に面した海岸沿いからファース トヒルにかけての地域に限定されており，キャ ピトルヒルやクィーンアン地区はまだ部分的に しか開発されていなかった口本人や中国人が 居住していた地区は，シアトルで最も古くから 発達した旧中心地区であり，都心業務地区の北 と東への拡大から取り残され，19世紀末ごろに は建物の老朽化が進み，人口密度の高い低家賃 地区となっていたところである。なお，第 1 期 の末ごろ (1900～) には, 日系人の居住地区は, 次第にファーストヒル寄り（東側）に拡大・移 動し始めて行く。

この時期，シアトルに居住していた日系人の 人口構成を詳しく把握することは資料的に困難 である。しかし，初期移民社会の例にもれず， 大部分が “渡り鳥”的出稼者の青壮年層単身男 性であり，性比や年齢構成の均衡を欠いた構成 であったと推定される。言わば，ミヤモトの言 う「フロンティア期」の様相を呈していたと先) える。

2) 第 2 期 $(1907 \sim 1930)$

こうした初期移民社会のフロンティア的状況 からの脱却・変容は，一般に家族世帯が増加し 定住化への志向が強まるにつれ進行するが，ミ ヤモトによればシアトルの日系移民コミュニテ

32）時期区分の基準となる年次および各時期の名称については，ミヤモトやヤナギサコ他の研究を参照した。 Miyamoto, S. F., 'Social Solidarity among the Japanese in Seattle', Univ. of Washington Publication in Social Sciences, 2-2, 1939, pp. 57-130 (reprinted 1981, 1984), Watanabe, T. M., A Report from the Japanese American Community Study, Dept. of Anthropology, Univ. of Washington (by Yanagisako, S. J., D. L. Leonetti, J. R. McGough, and L. L. Newell), 1977, 38p.

33）前掲32） Miyamoto, および Schmid, C. F., C. E. Nobbe, and A. E. Mitchell, Non-white Races, State of Washington, Washington State Planning and Community Affairs Agency, 1968, 132p., Schmid, C. F. and W. W. McVey, Jr., Growth and Distribution of Minority Races in Seattle, Washington, The Seattle Public Schools, 1964, 62p., Leonetti, D. L., Nisei Aging Project Report, Univ. of Washington, 1983, 62p., および前揭21)。

34）竹内幸次郎『米国西北部日本移民史』大北日報社，シアトル，1929（22-28頁）によれば，1879年ごろよりサンフラン シスコを経て西北部に移住した者が若干名あり，1880年代はじめにはシアトルで店を営む者が出始めたという。また，北 米日本人会商業会議所『シアトル案内』，1927，では移住民として居住し始めたのは1883年頃としている。

35）前掲32） Miyamoto, p. 65 .

36) フランク・ミヤモト氏の教示による。

37) Schmid, C. F. and S. E. Schmid, Growth of Cities and Towns, State of Washington, Washington State Planning and Community Affairs Agency, 1969, Figure 4:3(p.146), 参照。

38) 前掲37), Figure 4:2(p.145) およびpp.141-142, 参照。

39）ちなみに，『北米年鑑 1928年版』によると，1900年のシアトルにおける日系人の性比は507（女＝100につき男）であ り，それ以前はさらにこの值が高かったものと推測される（前掲32, Miyamoto, p. 85, Table Vから引用)。

40）前掲32） Miyamoto, p. 65, 参照。 

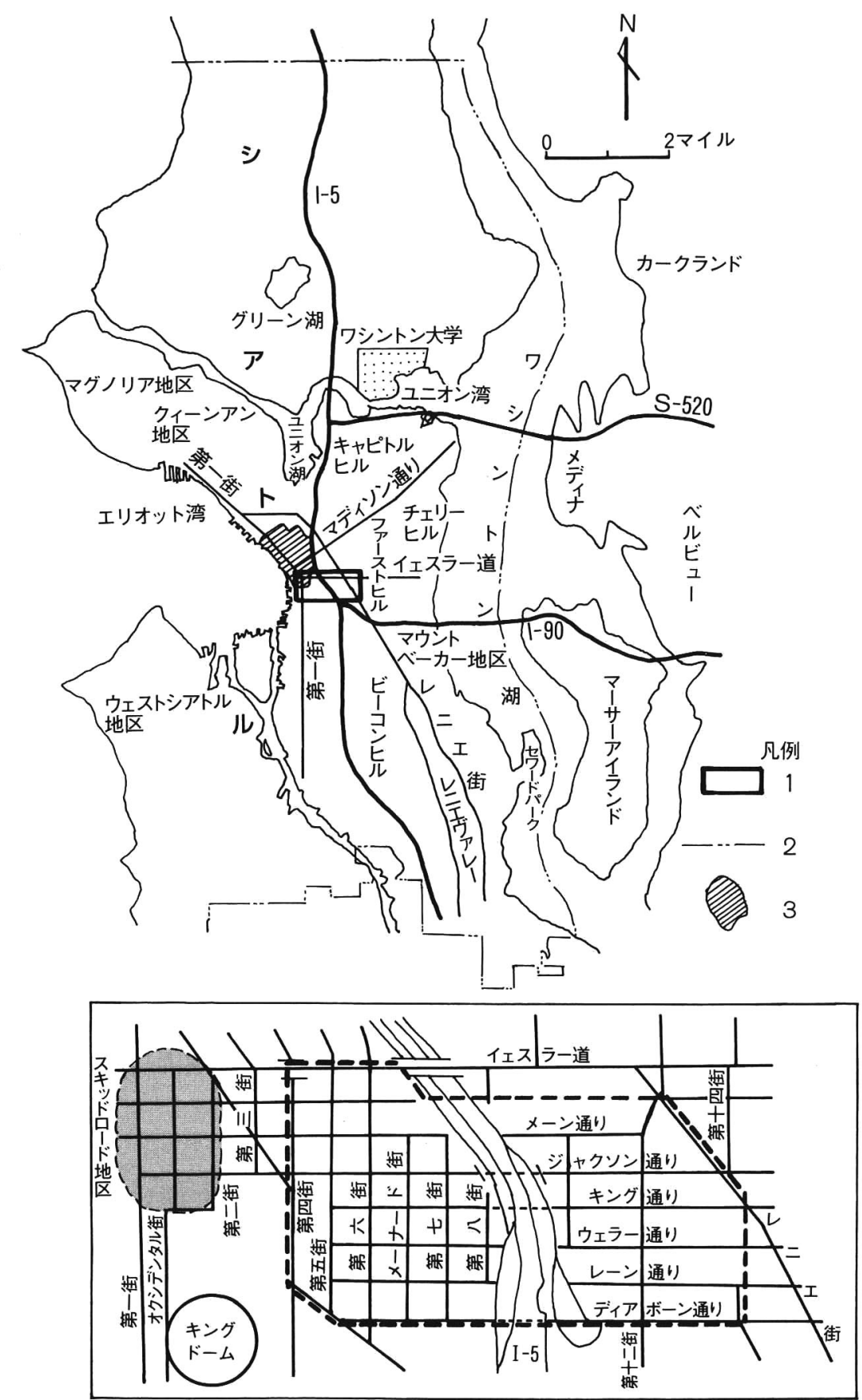

第1図 対象地域概況

1 : 拡大図 (下図) の範囲, 2 : シアトル市 (City of Seattle) の境界, 3 : ダウンタウンの範囲（概略）

I- 5 ：インターステート・ハイウェイ 5 番, I-90：インターステート・ハイウェイ90番,

S -520：ステート・ハイウェイ520番

下図（拡大図）の太い破線：「チャイナタウンーインターナショナル地区」(注78）の範囲 
イの場合，労働移民の制限に関する日米間「紳 士協定」締結（1907）のプロセスが，その一つ の転機となっていたというう。しかし，シアトル の場合，コミュニティの中核となる諸組織・団 体の一部は後述するようにすでに1900年前後か ら設立され始めており，定住化志向の芽生えは その頃から始ったと見るべきであろう。

シアトル市に扔ける日系人数は，1910年まで に急増して 6,127 人（市人口の $2.6 \%) ， 1920$ 年 7,874 人 $(2.5 \%)$ ，さらに 1930 年 8,448 人 (2.3\%) となり，1930年前後に戦前期における ピークを迎える。また，性比を見ると1913年 293 (女＝100につき男)，1917年257，1920年153 となり，1910年代末から急速に均衡化の方向に 向かったことが分かる。これとともに，現地生 の二世の占める割合も，1910年 $6 \% ， 1920$ 年 24\%，1930年47\%と急速に増加した。このよう な変化は，言うまでもなく，シアトルの日系人 社会が移働労働者の社会を脱し, 定住を志向す るエスニック・コミュニティへと転換していっ たことを示している。

次に市内における居住分布を見よう。ミヤモ トによれば，1912年の日系人人口分布図は第六 街とメーン通りを中心とする数街区に極度の集 中を呈していたというゔ。また，シュミッドも， 日系人居住地区は1912年になっても実質的に第
四街（西）～第八街（東)，イェスラー道（北） 〜ジャクソン通り（南）に囲まれた地区に限定 されていたとする(第 1 図, 参照)。

1920年の居住分布については, 市民住所録 (Polks City Directory）に基づいたミヤモトによ る地図，センサスデー夕によると思われるシュ ミッド他の地罳) (いずれもドットマップで表現) があり，かなり正確にそのパターンを把握でき る。すなわち, この頃, シアトルの日系人達は, ファーストヒルの南西斜面, 東西は第五街から 第十四街, 南北はイェスラー道からディアボー ン通りにかけての地区に集中し，密集居住核を 形成していた。しかし，ミクロに見れば，この 集中地区の外側，北側の都心地区や南のビーコ ンヒル北部，東のチェリーヒルあたりにも相当 数の人が居所をもっていた。ミヤモトは,こう した人口分布パターンについて，1912年からの 変化は経過年数が短かいことを考慮すれば，む しろ驚くべき流動性を示したと評価している。

3）第 3 期 (1930 1942)

シアトルの日系社会は, いわゆる「排日移民 法」の通過（1924年）後, 新規移入者の事実上 の途絶の影響が様々な形で出始めるが，その最 も端的な現われは1930年代における日系人人口 の減少である。人口構成の上では現地生二世が ますます増加し，1930年代前半には過半を占め

41）協定に示された初期日系人社会への批判に敏感になったこと，「早く金を稼いで日本に戻る」という目標の実現が容易 ではないことが認識されてきたこと, 年々の生活体験が適応をより容易にしたこと, そして協定自体が流入してくる移民 の性格を変化させたこと, などが理由として挙げられている。前揭32) Miyamoto, p. 65 .

42）数值は合衆国センサスによる。Ong, P. M., J. T. Fujita, and S. Chin, Asians in Washington: A Statistical Profile, Washington State Commission on Asian American Affairs, 1976, p. 24, 参照。

43）前揭39）と同資料。

44）前掲32) Miyamoto, p. 14, Table I から引用。

45）前掲32） Miyamoto, p. 66. ただし, 地図はレイドメーカー（Rademaker, John A.）の未出版のものを参照した模様であ り，論文中には呈示されていない。

46）前揭33）Schmid, Nobbe, and Mitchell, p. 62, および Schmid, C. F., 'Social Trends in Seattle', Univ. of Washington Publications in the Social Sciences, 14, 1944, pp. 131-149 (Chap. V).

47）前揭32) Miyamoto, p. 89, Figure I.

48）前掲33) Schmid, Nobbe, and Mitchell, p.63, Figure $3: 21$

49）前掲32） Miyamoto, pp.66. なお，この評価が妥当かどうかは即断できないが，同年の中国人の居住分布と比較した場 合，相対的に正しいと言える。前揭33）Schmid, Nobbe, and Mitchell, p. 65, Figure 3:23，参照。

50）合衆国センサスによるシアトル市の日系人人口は 1930 年 : 8,848 人, 1940 年 $: 6,975$ 人である。 
るようになった。また，「紳士協定」や移民法 改訂（1924）などの歴史的経緯により，一世の 結婚時期が限られたため，年齢構成上顕著なバ イモーダルのパターンが形成された。

この時期の居住分布に関しては, ミヤモトが 作成した1930年と35年の地図がある。このうち, 1930年の図が示すパターンは，1920年と基本的 に大きくは違わない。しかし，1935年の罒では かなり明らかな変化が認められる。すなわち， 集中居住地区が主として東の方向へ拡大し，そ の中心部における密度が低下して, 全体に一定 の範囲内にむしろ均等に分布するようになった。 また，住宅地として開発されてきた南方のビー コンヒル上やマウント・ベーカー地区にも若干 の居住が見られるようになった。このように， 1930年代，シアトルの日系人コミュニティは基 本的に集中地区を維持しつつも，外方分散と拡 大の動向を示し始めたと言えよう。しかし，こ のプロセスも1942年春の日系人強制立ち退きに よって突如中断されることになった。

\section{4) 第 4 期 (1945 1955)}

戦時の強制立ち退き令は基本的に1945年 1 月 までに解除され, 強制収容された日系人達の太 平洋岸地域への帰還が始まった。ミヤモトとオ ブライエン (O'Brien, Rober W.) によれば，そ の最初の 2 年間にシアトルに流入した日系人は 4,700人弱, そのうち戦前もシアトルに居住し ていた者は約4,100人程であった。1950年のシ アトル市の日系人人口は 5,778 人 と, なお立ち 退き前の水準には達せず，人口面での回復は 1950年代の半ばまでかかった。
戦後再形成された日系人コミュニティの人口 ピラミッド（1947年）の特色を見ると，1935年 時点のそれと大きく異ならず，ピークが高齢層 にずれたバイモーダルなパターンが呈示される。 現地生の比率は65\%となり，数の上でも「二世 の時代」に入ったことを示している。なお，セ ンサスによる1950年のシアトル居住日系人は男 3,066 人，女 2,712 人であり，戦前に比しさらに 性比の均衡化が見られたが，この時期なお，や や男が多い状況であった。

居住分布に関しては，シュミッド他が作成し た1950年時点での人口分布図があり，それによ ると, 南北はイェスラー道を中心に数ブロック, 東西は第五街から第二十五街付近にかけて細長 いはっきりした密集クラスターが形成されてい ることが分かる。すなわち, 戦前とは位置が少 しずれているが，それに近い位置に集中地区が 再形成され，外方への分散はまだ限られていた。 このように，戦後の回復期におけるシアトルの 日系人コミュニティは，人口と居住から見る限 り, 戦前のパターンに近い形で再形成されてお り，大きな変化は1950年代後半まで生じなかっ た。

5) 第 5 期 (1955 )

センサスによるシアトル市の日系人人口は， 1960 年 9,351 人と戦前の水準を上回るが，その 後70年, 80 年ともほほ 1 万人弱で大きな変化を 見せない。ところがシアトルーエヴァレット標 準大都市圏（SMSA）で見ると, 日系人人口は 80 年時点までに 17,535 人と増加していることか ら, 中心都市 (シアトル市) とその郊外市街化

51）シアトルの日系人人ロに占める現地生の割合は，1930年47\%，1935年53\%となる。前掲32） Miyamoto, p. 68, Table I, 参照。

52）前掲32) Watanabe, p. 8, 参照。

53）前掲32） Miyamoto, p. 92, Figure IV, 参照。

54）前揭32) Miyamoto, p. 90, Figure II, 及び p. 91; Figure III.

55) Miyamoto, S. F. and R. W. O'Brien, 'A Survey of Some Changes in the Seattle Japanese Community since Evacuation', Research Studies of the State College of Washington, 15(2), 1947, pp. 147-154.

56）合衆国センサスによる。

57）以下，前揭55）による。

58）前掲33) Schmid, C. F. and W. W. McVey, Jr. 
地域をあわせたシアトル大都市地域（以下，シ アトル地区）の日系人コミュニティの規模は大 きくなっていることが分かる。性比を見ると, 1960年時点で始めて女が男を上回り, その後こ の傾向が続いている。現地生 (二世，三世）の 割合は確実に増加し，1980年代には戦後流入し た日本人（いわゆる「戦争花嫁」や「新一世」）を 除いて，ほぼ完全に現地生世代のコミュニティ に転換した。

この時期, 日系人の居住パターンは大きく変 化した。シュミッドらが作成した1960年の日系 人人口分布図を見ると, イェスラー道あたりに 集中居住域をまだ残してはいるものの, ビーコ ンヒル上やレニエヴァレーに新たな集中地区が 出現し, 全体的に居住分散が進行したことが読 みとれる。1980年センサスに基づいた分布図で は，日系人の最多地区はビーコンヒルに移り， そこから南 (ないし南南東) 方向やユニオン湖 ・ユニオン湾北岸のワシントン大学付近に多い パターンが示される。なお，1970年から80年の 日系人人口の変化を見ると, 都心及びその南方 の地域において減少が激しい。すなおち，この 時期, 全体として日系人人口の市中心部での空 洞化，郊外部（特にシアトル市外）での増加が生 じてきたと言える。

しかし，こうした日系人人口の流動性につい ては世代による差異も考慮する必要がある。レ オネッティの調査では, 伝統的な日系居住地域 のコアー・エリアは一世と二世にとってなお重 要であり, 三世はキング郡内の東部などに広く 分散するが，中心に近い地区（ビーコンヒル，レ
ニエヴァレー）から完全に徹退したわけではな いことが示される。また, JACLの名簿 （1983）を分析した阿部も，日系人人口の高齢 化が，そのモビリティをやや低くし，古くから の居住地またはその近くに固執する傾向も残し たと指摘している。いずれにしても，1950年代 後半以降, シアトル地区における日系人コミュ ニティは居住分散・郊外化の基本的方向によっ てその空間的状況を大きく変えたが，古くから の居住地区の役割は，少なくとも1980年代まで はなお完全には消失しなかったと言える。

( 2 ) 日系営業施設の展開とエスニック・ビジ ネスの変容 都市に定着した移民エスニック集 団は，様々な特色ある小自営ビジネスを営み， そのテリトリーの中に自らの商業・業務地区を 形成する。アメリカの日系人の場合, 日本人町, 日本町, ジャパンタウンなどと称する地区がこ れにあたる。本節では，この日本人町の形成・ 変容を中心に，シアトルにおける日系人ビジネ ス活動の空間的展開を検討する。

1) 第 1 期 $(\sim 1907)$

フロンティア期の日系人営業活動の立地につ いては現段階で資料的に正確につかむことはで きない。しかし，竹内の著作 (1929) やその他 の情報を参照する限り, 当時の日系人ビジネス ・パイオニア達の経営する飲食店などの店は, 現在のキングドームの北側, 第一街から第三街 あたりにあり，日本人労働者の集中する地区と ほぼ重なっていたと推定される。なお，ミヤモ トによれば彼等の「レストラン，床屋，ホテ ル」は主として近くに住む労働者階級の白人を

59）前掲33) Schmid, Nobbe, and Mitchell, p. 64, Figure $3: 22$.

60) Puget Sound Council of Governments が作成。Washington State Commission on Asian American Affairs, Countdown: A Demographic Profile of Asian and Pacific Islanders in Washington State, 1982, p. 22 に記載。なお, この分 布図はセンサストラクト単位に日系人人口数を階級区分して示した図なので詳しい分布パターンは読みとれない。

61）前掲60に基づき，阿部がセンサス・トラクト別に分析したものによる。前揭21。

62）JACL（前揭30）及び Keiro Nursing Homeの名簿（年次の記載なし）にリストされたキング郡内の3,671世帯を対象 に実施した郵送アンケート調查。世帯分布の検討は，この3,671世帯の住所（ZIP コード）によるものと思われる。前掲 33)。

63）前掲21)。

64）前揭34)，及びフランク・ミヤモト氏の教示を参照。 
対象としたホスト社会指向型であったといゔ。 これは，当時の日系人コミュニティの規模が小 さかったことを考えればある程度うなづけるが, コミュニティの成長につれ，日系人のパイオニ ア・ビジネスは急速に自集団向けの機能を増大 させていったものと思われる。

2) 第 2 期 (1907 - 1930)

第 1 期の末頃から1930年頃までは，戦前の日 系人ビジネスが急速に伸長し，いわゆる日本人 町が成長・繁栄した時代である。この時期の日 本人町は，初期のパイオニア・ビジネスの立地 地域より少し山手 (東) 寄りの第六街とメーン 通りを中心とした地区に移動してきており，キ ング通り，ウェラー通りを中心としたチャイナ タウンと一部重なるような形で隣接していた。 この移動の原因と詳しい時期やプロセスについ てははっきりしないが，基本的に日系人居住地 区の東方への移動・拡大に追随する形で，商業 ・業務活動が初期のスキッドロード地区から離 脱・移動した現象ととらえることができよう。

1916年の市内日系営業施設（または営業者） 数とその構成（第 1 表）及びその分布（第 2 図） を見ると，当時市内には700近い諸種の日系営 業施設が成立しており，その85\%にあたる570 強の施設が「日本人町域内」に立地していた。 市内の他地区にはパイクプレース・マーケット 近くの小集積を除いて日系営業施設の立地はき わめて少なく，明確な単核的集積パターンをも つ日系商業・業務核 (日本人町) が形成されて いたと言える。この傾向は，1928年の状況を見 ても基本的に継続するが，「日本人町域内」の
第 1 表 シアトル市日系営業者・営業施設数

(1916年)

\begin{tabular}{|c|c|c|c|c|c|}
\hline 種 & $\begin{array}{l}\text { 日本人 } \\
\text { 町域内 }\end{array}$ & $\begin{array}{l}\text { 日本人 } \\
\text { 丁丁 域外 }\end{array}$ & 場所 & 計 & $\begin{array}{l}\text { 日本人町 } \\
\text { 域内の割 } \\
\text { 合 } 1 \text { ) }\end{array}$ \\
\hline 銀 行 & 3 & & & 3 & 100.0 \\
\hline 商社・輸出入商 & 9 & 1 & 1 & 11 & 90.0 \\
\hline 新聞・印刷所・書店 & 18 & 2 & & 20 & 90.0 \\
\hline 医療施設‧関係者 & 32 & 2 & & 34 & 94.1 \\
\hline 就労斡旋 & 5 & & 1 & 6 & 100.0 \\
\hline 各種専門的サービス業 & 16 & & 1 & 17 & 100.0 \\
\hline 雑貨·多品種店 & 22 & 4 & 1 & 27 & 84.6 \\
\hline 靴(修理‧販売) & 7 & 9 & & 16 & 43.8 \\
\hline 各種食料品店 & 29 & 22 & 8 & 59 & 56.9 \\
\hline 各種専門品店 & 10 & & & 10 & 100.0 \\
\hline 各種商店(その他) & 28 & 7 & & 35 & 80.0 \\
\hline 洗濯 · 理髮・美容等 ${ }^{2)}$ & 113 & 22 & & 135 & 83.7 \\
\hline 銭湯(日本風呂) & 10 & & & 10 & 100.0 \\
\hline 日本食レストラン & 38 & 3 & & 41 & 92.7 \\
\hline 洋食レストラン・カフェ & 30 & 9 & & 39 & 76.9 \\
\hline 娛＼cjkstart楽 & 29 & 1 & & 30 & 96.7 \\
\hline ホテル・アパート & 87 & 7 & & 94 & 92.6 \\
\hline 製造業（含洋服製造） & 48 & 4 & & 52 & 92.3 \\
\hline 修理‧大工・職人等 & 20 & 3 & & 23 & 87.0 \\
\hline 運 送 & 20 & 3 & & 23 & 87.0 \\
\hline 計 & 574 & 99 & 12 & 685 & 85.3 \\
\hline
\end{tabular}

その他 市場内出店 19

資料：『北米年鑑 1916年版」

1）不明を除く総数に対するパーセント

2）ダイウォーク業 (洗染業)を含む（以下同）

シェアーは70\%と多少低下した（第 2 表)。

伊藤が作成した盛時の日本人町の状況を示す 略地図によると, 店舗の密度から見て日本人町 の中心はメーン通りとジャクソン通り，第五街 から第 7 街までの数街区であり，特にメーン通 りには日系商店が連続して並んでいた模様であ る。日本人向きの業種として目につくものは, 風呂屋，旅館，飲食店（すし，うどんなどの日本 食）などであり，新しい日本人移民を最初に受 け入れる地区，“port of entry”の性格をよく表

65）前揭32） Miyamoto, p. 65

66）1906年の報告では，すでに“Japan town”が第二街から第八街まで拡大した状況が述べられている。Kanda, S. K., ‘The Japanese in Washington', Washington Magazine, 1(3), 1906, pp. 193-197.

67）便宜的に設定した区域，西は第一街の西側，東は第十二街の西側，北はイェスラー道の南側，南はディアボーン通りの 北側に囲まれた範囲に相当（第 1 図の街路名，参照）。

68）伊藤一男『北米百年桜』, 北米百年桜実行委員会，1969，の挿絵，「シアトル旧日本人街」「シアトル旧日本人街明細図」 の 2 葉。特定年次の状況を表わしたものではなく, 1920年代中頃の状況を前後ミックスして表現したという。主要な店舗 のみ示した図と解される。

69）前揭15), p. 282, 参照。 


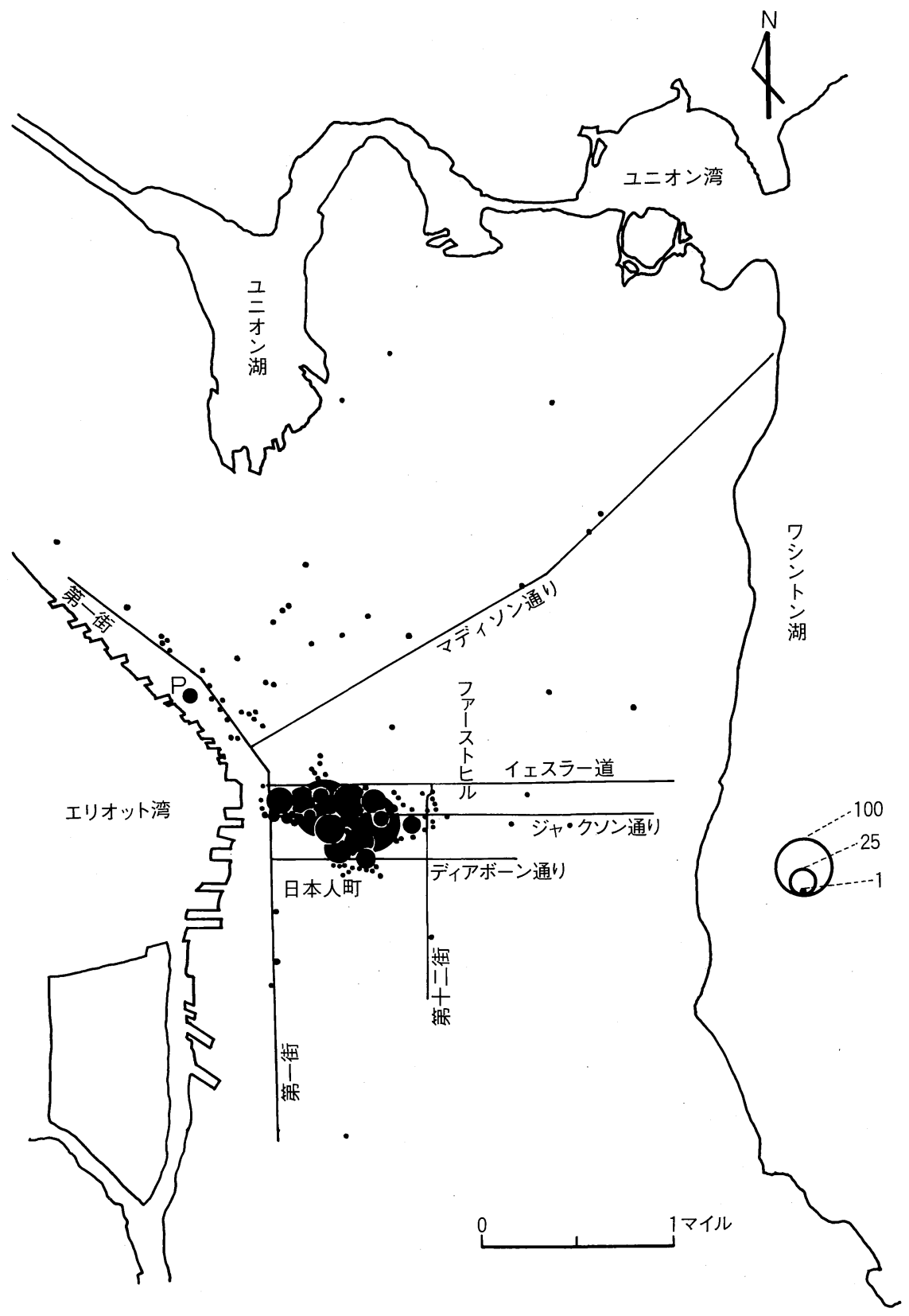

第 2 図 日系営業施設の分布（1916年）

P：パイクプレース・マーケット，資料：『北米年鑑 1916年版』

わしている。

しかし,このような日本人町の隆盛は, シア トルのみではなく，周辺の農村部を含めたより 広い地域に㧍ける日系人人口の増加によって可
能になったと思われる。日系新聞社, 銀行, 病 院・医院, 法律事務所, 保険, 私設労働周旋所 (いわゆる「桂庵」)，貿易商などの存在（第 1,2 表, 参照) は, 広い地域の日系コミュニティへ 
第 2 表 シアトル市日系営業者・営業施設数

(1928年)

\begin{tabular}{|c|c|c|c|c|c|}
\hline 種 & $\begin{array}{l}\text { 日本人 } \\
\text { 町域内 }\end{array}$ & \begin{tabular}{|l} 
日本人 \\
町域外
\end{tabular} & 場所 & 計 & $\begin{array}{l}\text { 日本人町 } \\
\text { 域内の割 } \\
\text { 合1) }\end{array}$ \\
\hline 銀 行 & 2 & 2 & & 4 & 50.0 \\
\hline 商社・輸出入商 & 8 & 2 & 14 & 24 & 80.0 \\
\hline 新聞·印刷所 - 書店 & 14 & 1 & & 15 & 93.3 \\
\hline 医療施設‧関係者 & 28 & 3 & 2 & 33 & 84.8 \\
\hline 就労斡旋 & 7 & 1 & & 8 & 87.5 \\
\hline 各種専門的サービス業 & 14 & 5 & 9 & 28 & 73.7 \\
\hline 雑貨·多品種店 & 37 & 3 & 1 & 41 & 92.5 \\
\hline 靴(修理・販売) & 9 & 12 & & 21 & 42.9 \\
\hline 各種食料品店 & 61 & 73 & & 134 & 45.5 \\
\hline 各種専門品店 & 12 & & & 12 & 100.0 \\
\hline 各種商店(その他) & 28 & 9 & & 37 & 75.7 \\
\hline 洗濯·理髮·美容等 & 104 & 67 & & 171 & 60.8 \\
\hline 錢湯(日本風呂) & 6 & & & 6 & 100.0 \\
\hline 日本食レストラン & 32 & 2 & & 34 & 94.1 \\
\hline 洋食レストラン・カフェ & 21 & 5 & & 26 & 80.8 \\
\hline 娛＼cjkstart楽 & 6 & & & 6 & 100.0 \\
\hline ホテル・アパート & 122 & 48 & & 170 & 71.8 \\
\hline 製造業(含洋服製造) & 28 & 4 & & 32 & 87.5 \\
\hline 修理·大工・職人等 & 11 & 2 & & 13 & 84.6 \\
\hline 自動車関連 & 16 & 6 & 2 & 24 & 72.7 \\
\hline 運送 & 10 & & & 10 & 100.0 \\
\hline 温室·苗木園・庭師 & & 2 & & 2 & 0.0 \\
\hline その他 & 8 & & & 8 & 100.0 \\
\hline 計 & 584 & 247 & 28 & 859 & 70.3 \\
\hline
\end{tabular}

その他 市場内出店 66 , 行商 31

資料：『北米年鑑 1928年版』

1）不明を除く総数に対するパーセント

のサービス機能，その基地としての機能，の存 在を示唆している。また, 異常に多いホテルの 数や洗濯屋，グロッサリーなどの存在は，顧客 が日系人のみならずホスト社会の住民や他集団 の労働者にも広がっていたことを物語る。

3）第 3 期 (1930 1942)

シアトルの日系社会が停滞・閉塞期を迎えた 1930年代に入ると，日系人ビジネスの状況にも かなりの変化が見られるようになる。1936年の 日系営業施設数（市場内出店や行商を除く）は 950で，1928年より増加したが，「日本人町域
内」は457と減少し，そのシェアーも50\%弱と なった (第 3 表)。その分布状況を見ても（第 3 図)，日本人町域の中心的集積の他，その東側 のファーストヒル上やダウンタウン海岸寄りに 小集積が現われ, 総体的に都心及び都心周辺地 区全体への分散傾向が顕著になってきたことが 認められる。業種別の動向を見ると, 1928年か らの減少が目立つものは, 日系新聞, 助産婦, 洋服業，球場，風呂屋，床屋，和食堂などであ り，これらは主として日系人を主な顧客とした

第 3 表 シアトル市日系営業者・営業施設数

（1936年）

\begin{tabular}{|c|c|c|c|c|c|}
\hline 業 & \begin{tabular}{|l|} 
旦本人 \\
町域内
\end{tabular} & $\begin{array}{l}\text { 旦本人 } \\
\text { 町域外 }\end{array}$ & 場所 & 計 & $\begin{array}{l}\text { 日本人町 } \\
\text { 域内の割 } \\
\text { 合 } 1 \text { ) }\end{array}$ \\
\hline 銀 行 & & 2 & & 2 & 0.0 \\
\hline 商社·輸出入商 & 10 & 4 & 9 & 23 & 71.4 \\
\hline 新聞 - 印刷所 - 書店 & 11 & & & 11 & 100.0 \\
\hline 医療施設・関係者 & 19 & 12 & & 31 & 61.3 \\
\hline 就労斡旋 & 9 & & & 9 & 100.0 \\
\hline 各種専門的サービス業 & 12 & 5 & 2 & 19 & 63.2 \\
\hline 雑貨·多品種店 & 17 & 6 & & 23 & 73.9 \\
\hline 靴(修理・販売) & 8 & 12 & & 20 & 40.0 \\
\hline 各種食料品店 & 51 & 127 & 1 & 179 & 28.7 \\
\hline 各種専門品店 & 10 & 2 & & 12 & 83.3 \\
\hline 各種商店 (その他) & 36 & 18 & 4 & 58 & 66.7 \\
\hline 洗濯・理髮・美容等 & 72 & 98 & & 170 & 42.4 \\
\hline 銭湯(日本風呂) & 3 & & & 3 & 100.0 \\
\hline 日本食レストラン & 20 & 1 & & 21 & 95.2 \\
\hline 洋食レストラン・カフェ & 32 & 13 & & 45 & 71.1 \\
\hline 娛 楽 & 4 & & & 4 & 100.0 \\
\hline ホテル・アパート & 87 & 91 & 1 & 179 & 48.9 \\
\hline 製造業(含洋服製造) & 20 & 7 & 2 & 29 & 74.1 \\
\hline 修理 · 大工·職人等 & 6 & 9 & & 15 & 40.0 \\
\hline 自動車関連～～ & 8 & 5 & & 13 & 61.5 \\
\hline 運 送 & 8 & 3 & & 11 & 72.7 \\
\hline 温室・苗木園・庭師 & 9 & 49 & 6 & 64 & 15.5 \\
\hline その他 & 5 & 4 & & 9 & 55.6 \\
\hline 計 & 457 & 468 & 25 & 950 & 49.4 \\
\hline
\end{tabular}

その他 市場内出店 $45^{2)}$, 行商 34

資料：『北米年鑑 1936年版』

1) 不明を除く総数に対するパーセント

2) 野菜小売商を含む

70）田村・坂ロも，シアトルの日本人町や日本語新聞の活動を分析する上で，シアトル以外の流動的な労働人口を考える必 要があることを指摘している。田村紀雄・坂口満宏「シアトル初期の日本語新聞」; 東京経済大学人文自然科学論集, 92 , pp. 39-70.

71）竹内は, シアトルの日系人営業中, 白人を顧客とする割合が高い業種として, 野菜果物の行商, ダイウォーク業（洗染 業)，グロサリー業などを挙げている。また，伊藤は日本人経営のホテルが多くの白人を客としていること，日本人人口 の割に洗濯屋や洋食屋が多いのは白人相手の営業であったこと, などを指摘した。前掲34), pp. 325～360, 前掲68), p. 616, p. 929. 


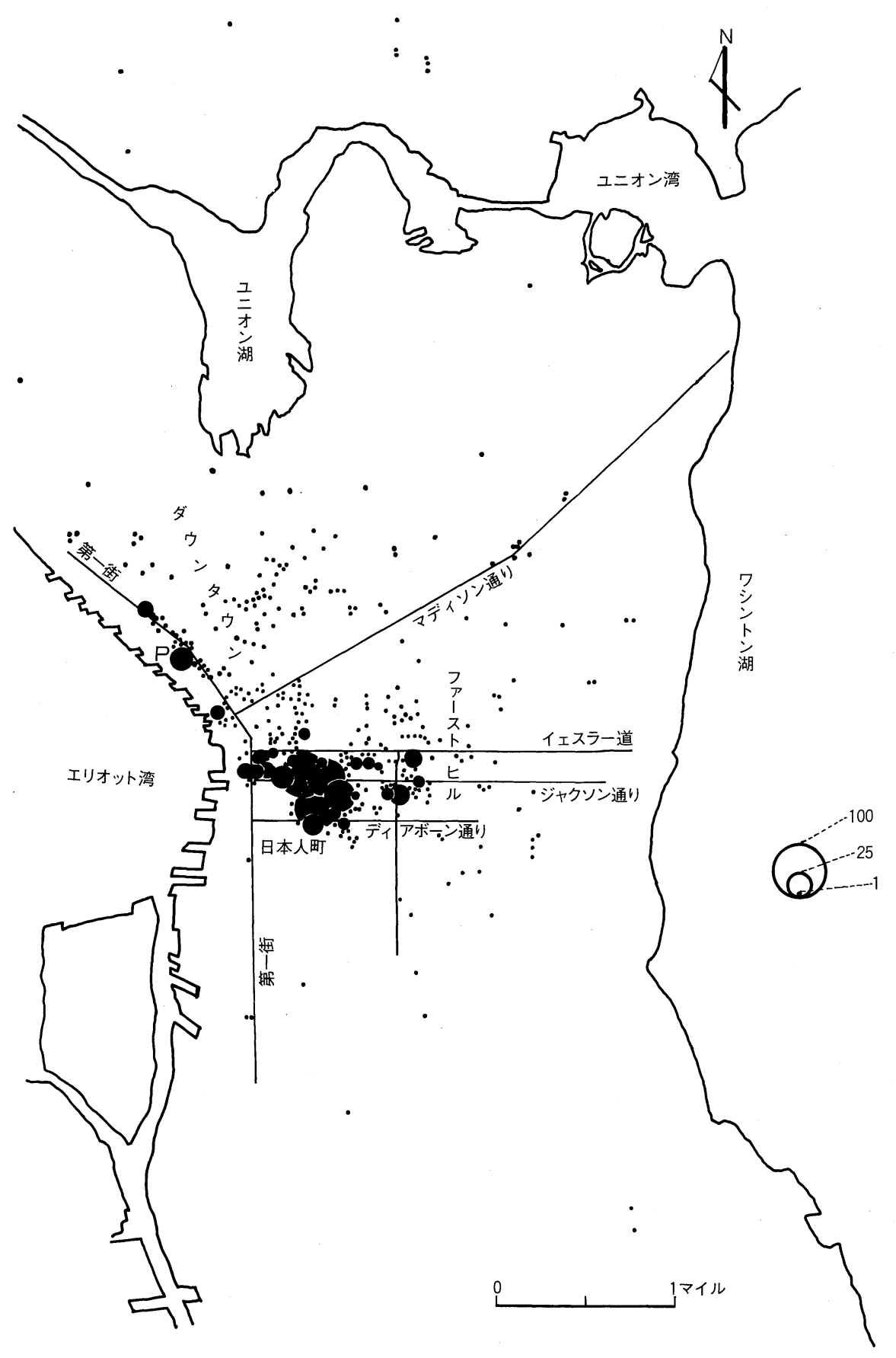

第3 図 日系営業施設の分布 (1936年)

P：パイクプレース・マーケット, 資料：『北米年鑑 1936年版』 
業種と考えられる。それに対してむしろ増加傾 向を示しているのは，一般社会指向型と考えら れるグロッサリーなど食品店，洗濯屋，ホテル， 洋食レストラン，花屋などである。このように， シアトルの日系人ビジネスは，1930年代に入っ て自集団指向型ビジネスの後退と一般型ビジネ スの強化の 2 つの方向が現われ，これらと関連 して空間的には「日本人町域内」のシェアーの 減少，全体としての分散化傾向が見られた。

4) 第 4 期 (1945 1955)

戦後の日系人ビジネスの復興状況に関しては, 伊藤の記述がまず参考になる。それによると 1945年 9 月の「メーン食堂」の開店を嚆矢に, 食堂, ホテル，洗濯屋，床屋，グロッサリーな どが，主として旧日本人町の域内に次々に復活 していった。1949年時点で確認される市内日系 人ビジネスは 420 で (以下, 第 4 表), なお復興 の途上にあることが分かる。「日本人町域内」 のシェアーは50\%強で1936年とほほ同じであり， かなり縮小した形ながらほぼもとの日本人町の 位置に戦後の日系商業・業務地区が再興された と言える。業種構成の上では, 桂庵や日本風呂 など, 昔の日本人町を特色づけた施設の一部は 再び隆盛を見ることがなかったが, 食料品店や その他の商店, 洗濯屋, レストラン（特に洋食 店）床屋，球場などは復活してきており，特に ホテル・アパート業の復興ぶりが目につく。

5) 第 5 期 (1955 )

シアトルの日系営業施設の状況も，1960年代 からは大きな変容期を迎える。日系営業者の総 数は, 1967年時点において, シアトル市内655,
第 4 表 シアトル市日系営業者・営業施設数

(1949年)

\begin{tabular}{|c|c|c|c|c|c|}
\hline 業 & $\mid \begin{array}{c}\text { 日本人 } \\
\text { 町域内 }\end{array}$ & $\mid \begin{array}{l}\text { 日本人 } \\
\text { 町域外 }\end{array}$ & 場所 & 計 & $\begin{array}{l}\text { 日本人町场 } \\
\text { 合 } 1 \text { () }\end{array}$ \\
\hline 商社·輸出入商 & 5 & 4 & & 9 & 55.6 \\
\hline 新聞 - 印刷所 - 書店 & 6 & & & 6 & 100.0 \\
\hline 医療施設・関係者 & 14 & 5 & & 19 & 73.7 \\
\hline 各種専門的サービス業 & 19 & 3 & 3 & 25 & 86.4 \\
\hline 雑貨·多品種店 & 3 & 1 & & 4 & 75.0 \\
\hline 靴(修理‧販売) & 3 & 1 & & 4 & 75.0 \\
\hline 各種食料品店 & 22 & 19 & & 41 & 53.7 \\
\hline 各種専門品店 & 5 & 1 & & 6 & 83.3 \\
\hline 各種商店(その他) & 21 & 16 & & 37 & 56.8 \\
\hline 洗濯·理髪·美容等 & 22 & 23 & 3 & 48 & 48.9 \\
\hline 銭湯(日本風呂) & 1 & & & 1 & 100.0 \\
\hline 日本食レストラン & 4 & & & 4 & 100.0 \\
\hline 洋食レストラン・カフェ & 14 & 7 & & 21 & 66.7 \\
\hline 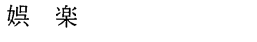 & 7 & & & 7 & 100.0 \\
\hline ホテル・アパート & 58 & 92 & 1 & 151 & 38.4 \\
\hline 製造業（含洋服製造） & 1 & 3 & 1 & 5 & 25.0 \\
\hline 修理·大工・職人等 & 4 & 7 & & 11 & 36.4 \\
\hline 自動車関連 ～～～ & 2 & 8 & & 10 & 20.0 \\
\hline 温室・苗木園 · 庭師 & & 5 & & 5 & 0.0 \\
\hline その他 & 1 & 4 & 1 & 6 & 20.0 \\
\hline 計 & 212 & 199 & 9 & 420 & 51.6 \\
\hline
\end{tabular}

資料：『全米日系人住所録 1949 年版』新日米新聞社

1）不明を除く総数に対するパーセント

近郊を含めたシアトル地区（大都市地域）で674 と戦前の水準に近い勢いとなった。しかし，こ のうちの半数近くは戦前にも増して盛んになっ たホテル・アパート業と戦後急速に増加した温 室・苗木園・庭園業で, 他の業種は概ね戦前よ り数を大きく減らしている(第 5 表)。1973年時 点では, このうち, ホテル・アパート業が大き く減少し(138軒), これが全体の営業者数を 627 と若干減少させる結果となった (表省略)。 同業種の減少は, 1983年時点でさらに激しく (第 6 表)，91年現在では日系人の手になるホテ

72）伊藤一男『アメリカ春秋八十年』，PMC 出版社，1982，pp. 168-170，参照。

73）ミヤモトとオブライエンも, 戦後早い時期の日系人のビジネス・センターは, 戦前とほぼ同じ位置にある旨, 記述して いる。前揭55)。

74）日本風呂屋は「橋立湯」1 軒のみ復活したが，建築・衛生規則により1960年代で姿を消した。前揭68)，p. 991，及び 聴取による。

75）第 5〜 7表において「シアトル市外（近郊）」とした地域は, JACLの日系人住所録の対象地域（Greater Seattle \& Vicinity）のうち，実質的なシアトル大都市地域に含まれると考えられる Bellevue, Kirkland, Renton, Mercer Isl., Bothell, Des Moins, Lynwood, Redmond, Edmonds, Tukwila な゙゙一括した地域を指す。 
第 5 表 シアトル地区日系営業者・営業施設数

（1967年）

\begin{tabular}{|c|c|c|c|c|c|}
\hline \multirow[b]{2}{*}{ 業 } & \multicolumn{3}{|c|}{ シアトル市 } & \multirow{2}{*}{$\begin{array}{l}\text { シアト } \\
\text { 儿市外 } \\
\text { (近郊) }\end{array}$} & \multirow[b]{2}{*}{ 計1) } \\
\hline & 総 数 & 位置 & $\begin{array}{l}\text { 旧日本人 } \\
\text { 町域内 }\end{array}$ & & \\
\hline 金融・保険 & 15 & 7 & 3 & & 15 \\
\hline 商社・輸出入商 & 13 & 2 & 1 & & 13 \\
\hline 新聞 - 印刷所 - 書店 & 2 & & & & 2 \\
\hline 医療施設‧関係者 & 43 & 3 & 4 & 3 & 46 \\
\hline 各種専門的サービス業 & 23 & 3 & 6 & 1 & 24 \\
\hline 雑貨·多品種店 & 13 & & 3 & & 13 \\
\hline 各種食料品店 & 45 & & 10 & & 45 \\
\hline 各種専門品店 & 17 & & 9 & & 17 \\
\hline 各種商店(その他) & 33 & & 7 & & 33 \\
\hline 洗濯 · 理髮 · 美容等 & 50 & 2 & 14 & 2 & 52 \\
\hline レストラン & 23 & 1 & 14 & & 23 \\
\hline 一般サービス業 & 5 & & & & 5 \\
\hline 娛＼cjkstart楽 & 5 & & 1 & & 5 \\
\hline ホテル・アパート & 220 & & 37 & & 220 \\
\hline 裁縫・洋服製造 & 3 & 1 & 2 & & 3 \\
\hline 修理 · 大工 · 建築関係 & 13 & 1 & 1 & 1 & 14 \\
\hline 自動車関連 & 39 & & 4 & 1 & 40 \\
\hline 温室·苗木園・庭園業 & 92 & & 1 & 11 & 103 \\
\hline その他 & 1 & & & & 1 \\
\hline 計 & 655 & 20 & $\begin{array}{c}117 \\
\left(17.9^{2)}\right)\end{array}$ & 19 & 674 \\
\hline
\end{tabular}

資料 : JACL Seattle Chapter: Greater Seattle \& Vicinity Japanese Telephone Directory, 1967

1）シアトル市総数とシアトル市外（近郊）との総計 (以下同)

2）位置不明を除くシアトル地区計に対するパーセント

ル・アパートは僅かに 2 軒となってしまった (第 7 表)。また，温室・苗木園・庭園業も，資 料年次では73年をピーク（122施設）とし，その 後減少している。代って, 80年代から急速に増 加したのが, 法律事務所, 各種コンサルタント などの専門的サービス業と医療施設・関係者で, 専門的教育を受けた三世のビジネス界への進出 を物語っている(以上 6,7 表参照)。また，レ ストラン業への進出も80年代後半には再び顕著 となった。これらのビジネスの多くは，基本的 にどの集団に対しても開かれた一般型の性質を もっているものと推測される。

ビジネス活動の空間的パターンの上でも大き な変化が生じた。「日本人町域内」に相当する
第 6 表 シアトル地区日系営業者・営業施設数

（1983年）

\begin{tabular}{|c|c|c|c|c|c|}
\hline \multirow[b]{2}{*}{ 業 } & \multicolumn{3}{|c|}{ シアトル市 } & \multirow{2}{*}{$\begin{array}{l}\text { シアト } \\
\text { ル市外 } \\
\text { (近郊) }\end{array}$} & \multirow[b]{2}{*}{ 計 } \\
\hline & 総 数 & 位置 & $\begin{array}{l}\text { 旧日本人 } \\
\text { 町域内 }\end{array}$ & & \\
\hline 金融・保険 & 24 & 3 & 5 & 6 & 30 \\
\hline 商社・輸出入商 & 62 & 22 & 2 & 2 & 64 \\
\hline 新聞·印刷所 - 書店 & 7 & & 4 & & 7 \\
\hline 医療施設‧関係者 & 75 & 8 & 1 & 25 & 100 \\
\hline 各種専門的サービス業 & 125 & 18 & 17 & 22 & 147 \\
\hline 雑貨·多品種店 & 14 & & 4 & 4 & 18 \\
\hline 各種食料品店 & 24 & & 6 & 2 & 26 \\
\hline 各種専門品店 & 27 & & 6 & 3 & 30 \\
\hline 各種商店(その他) & 41 & 5 & 10 & 2 & 43 \\
\hline 洗濯·理髪·美容等 & 35 & & 5 & 6 & 41 \\
\hline レストラン & 37 & 1 & 16 & 6 & 43 \\
\hline 一般サービス業 & 1 & & & 1 & 2 \\
\hline 娛 楽 & 4 & & 1 & & 4 \\
\hline ホテル・アパート & 37 & 1 & 4 & 2 & 39 \\
\hline 裁縫・洋服製造 & 10 & 1 & 1 & & 10 \\
\hline 修理 · 大工 · 建築関係 & 31 & 3 & 1 & 4 & 35 \\
\hline 自動車関連 & 17 & & 2 & 2 & 19 \\
\hline 温室 ·苗木園 - 庭園業 & 95 & & & 13 & 108 \\
\hline その他 ～～～～ & 7 & 1 & 1 & 1 & 8 \\
\hline 計 & 673 & 63 & $\begin{array}{r}86 \\
\left(12.1^{11}\right)\end{array}$ & 101 & 774 \\
\hline
\end{tabular}

資料：JACL Seattle Chapter：1983 Japanese Community Directory, Greater Seattle \& Vicinity

1）位置不明を除くシアトル地区計に対するパーセント

区域に立地する営業施設数のシアトル地区全体 に対する割合は 67 年時点で $20 \%$ を割り，その後 徐々に低下して91年現在10\%を下まわるように なった。また, ベルビューなどシアトル近郊の シェアーも，80年代以降急速に高まり，91年現 在ほぼ 4 分の 1 に達した（以上第 $5 \sim 7$ 表, 参 照)。1983年のシアトル市主要部日系営業施設 の分布を見ると（第4 図), 戦前(1936年) と比 較する時，その変化は明瞭である。すなわち，

1 ）いわゆる日本人町の集積が顕著に縮小した こと，2）ダウンタウン内ではパイクプレース ・マーケットや第 1 街沿いの集積が消え，より 東寄りの中心オフィス街に集中する傾向が見ら れること，3）旧「日本人町域」の東側やビー コンヒル上にも小集積が認められること，そし

76）この日系人経営ホテル・アパート業の衰退の原因としては，1970年前後から厳しくなった行政的規制による改修要請に 資本力の乏しい日系人経営者が対応できなかったことが挙げられる(もとホテル経営者からの聴取による)。 
第 7 表 シアトル地区日系営業者・営業施設数

(1991年)

\begin{tabular}{|c|c|c|c|c|c|}
\hline \multirow[b]{2}{*}{ 業 } & \multicolumn{3}{|c|}{ シアトル市 } & \multirow{2}{*}{$\begin{array}{l}\text { シアト } \\
\text { ル市外 } \\
\text { (近郊) }\end{array}$} & \multirow[b]{2}{*}{ 計 } \\
\hline & 総 数 & 位置 & $\begin{array}{l}\text { 旧日本人 } \\
\text { 町域内 }\end{array}$ & & \\
\hline 金融・保険 & 11 & & 1 & 3 & 14 \\
\hline 商社・輸出入商 & 8 & 1 & 1 & 1 & 9 \\
\hline 新聞·印刷所・書店 & 8 & & 4 & 1 & 9 \\
\hline 医療施設‧関係者 & 62 & 7 & 1 & 43 & 105 \\
\hline 各種専門的サービス業 & 118 & 10 & 11 & 30 & 148 \\
\hline 雑貨·多品種店 & 13 & & 3 & 2 & 15 \\
\hline 各種食料品店 & 15 & & 3 & 2 & 17 \\
\hline 各種専門品店 & 34 & & 6 & 6 & 40 \\
\hline 各種商店(その他) & 41 & 2 & 5 & 6 & 47 \\
\hline 洗濯・理髪・美容等 & 13 & 1 & 4 & 4 & 17 \\
\hline レストラン & 66 & & 11 & 38 & 104 \\
\hline 一般サービス業 & 3 & & & 1 & 4 \\
\hline 娛＼cjkstart楽 & 1 & & 1 & & 1 \\
\hline ホテル・アパート & 2 & & 1 & & 2 \\
\hline 裁縫・洋服製造 & 3 & & & & 3 \\
\hline 修理 · 大工·建築関係 & 34 & 4 & 4 & 5 & 39 \\
\hline 自動車関連 & 7 & & 2 & 3 & 10 \\
\hline 温室·苗木園・庭園業 & 59 & 1 & & 10 & 69 \\
\hline その他 & 5 & & & 2 & 7 \\
\hline 計 & 503 & 26 & $\begin{array}{r}58 \\
\left(9.1^{1 \prime}\right)\end{array}$ & 157 & 660 \\
\hline
\end{tabular}

資料：JACL Seattle Chapter: Japanese American Community Directory, Greater Seattle \& Vicinity, 1991

1）位置不明を除くシアトル地区計に対するパーセント

て4）全体としてシアトル市内に広く分散する 傾向が読みとれること，などである。このよう に，シアトルの日系人ビジネスは，1960年代以 降，急速に空間的に分散，郊外化し，それとと もに日本人町として知られた商業・業務核も徐 々に衰退・縮小の方向をたどってきた。

ところで，この旧日本人町が位置していたシ アトル都心地区南縁, イェスラー道の南側の地 区は，もともと日系の諸施設の他に中国系の施
設やフィリピン系移民の居住が見られた地区で あり，全体として言わば「アジア人町」とでも 言うべき性格を備えていた。戦後, 建物の老朽 化と世帯の離脱が進んだこの地区では，1970年 代からアジア人町的な歴史的特性を保存しつつ, 住宅と歩行者指向的な商業・業務の再活性化を 目指す都市再開発事業が進められてきた（第 1 図, 参照)。現在, 日系の諸営業施設は, この地 区の北西部，かつて日本人町の中心であったメ ーン通り, ジャクソン通り, 第六街を中心とし た地区に，日本食レストランなど20軒程の小集 積を残しており，他のアジア系 (特に中国系) 施設と混在する形ながらも，かろうじて「日本 人町」的雲囲気を残している。

（３）エスニック共同組織の発達とコミュニテ イ施設の展開 移民エスニック集団は，一般に， その存続・発展の基礎的戦略として, 集団内の 様々な相互扶助や共同活動を行い，そのための 組織・制度を発達させる。 シア9 系人の場合も，様々な政治的・社会的・経済的 ・文化的な契機によるエスニック共同組織（民 族的共同組織）を発達させてきた。ここでは, そうした組織の発達と, その本部あるいは中心 となる施設 (以下，コミュニティ施設）の空間的 展開を検討する。

\section{1) 第 1 期 $(\sim 1907)$}

シアトルにおける日系人のエスニック組織・ 団体の設立は, 特に宗教的組織が早く, 一番古 いと思われる浸礼派 (バブテスト派) の組織は, 1892年に発足している。その後, 1901年本派本

77）高津斌彰「シアトルにおけるエスニック=セグリゲーションと都市的土地利用・都市再開発」（G. H. カキウチ先生退官 記念会編『アメリカ・カナダの自然と社会』大明堂, 1990)，pp. 367-386，参照。

78）事業の正式名称は「シアトル・チャイナタウンーインターナショナル地区保存開発事業」, また, 地区の主要部は国の歴 史的地区 (National Register of Historic Places) にも登録されている。Seattle Department of Community Development, Seattle Chinatown International District: An Investment Guide, 1988, 17p., City of Seattle, Historic Preservation in Seattle: A Guide to Incentives and Procedures, 1991, 6p., 及び前揭22), 参照。

79）杉浦 直「日系人社会と民族的組織」，地理，36-5，1991，pp. 44-47.

80）坂口は，外務省外交史料館所蔵『在外本邦ノ神祠並寺院教会取調一件』により，シアトル日本人浸礼教会の創立を 1892 年 4 月としている。シアトル日本人基督教会同盟の記念誌では, 浸礼教会の創始者の伝道開始またはキリスト教青年会の 結成が1892年, 教会そのものの創立は1899年である旨, 記述している。坂口満宏「アメリカ西北部日本人移民年表 $(1)$ 一『大北日報』にみる日本人キリスト教会一」, 同志社大学人文科学研究所キリス卜教社会問題研究, 34, 1986, pp. 179-240，シアトル日本人基督教会同盟『六十周年記念史」，1974，306p. 


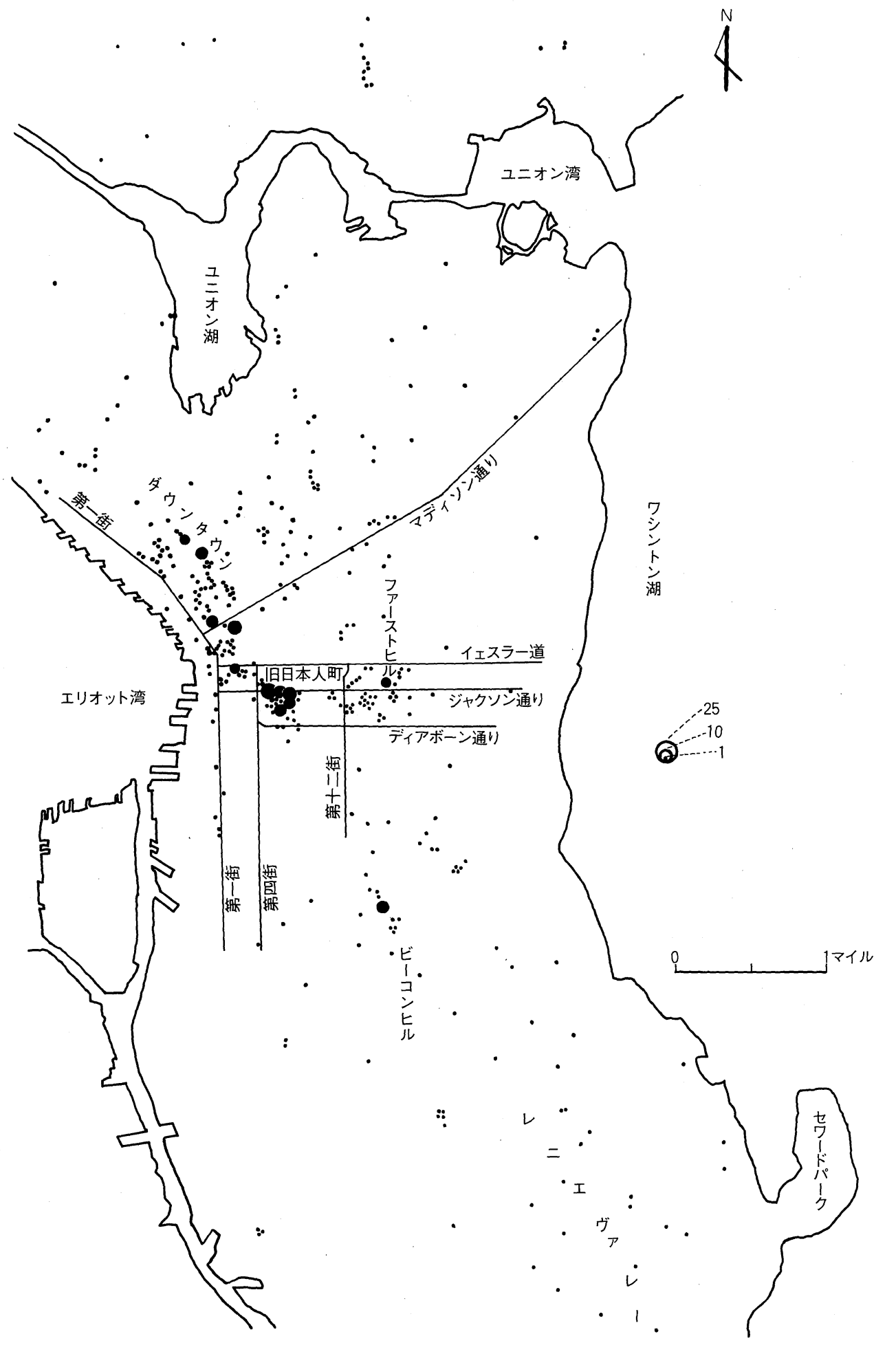

第 4 図 日系営業施設の分布（1983年）

資料：第 6 表と同 
願寺派の仏教会, 1904年美以教会（メソジスト 派)，1906（または1907）年長老教会（プレスビテ リアン派)，1907年組合教会 (コングレゲーショナ ル派)，さらに1908年聖公会 (トリニティ・ミッ ション, 後のセント・ピータース・エピスコパル パリッシュ）と，日系の教会が相継いで誕生し た。また，在シアトル日系人の最も中心的な組 織である日本人会は1900年に組織されている。 社交・互助的組織も，1907年までにいくつか発 足した。このように，シアトルにおいては， 1900年前後から各種のエスニック組織が結成さ れ, 社会的リーダーシップも確立し始めていた。 これら初期の組織の本部や中心的施設は, 住所 から見る限りほとんどがメーン通り，第四〜八 街あたり（第 1 図, 参照) の日本人町の中央部 にあり，日系人のコミュニティ活動，ビジネス 活動，そして居住域は空間的に重なっていたと 推測される。

2）第 2 期（1907～1930)
1916年の日系人住所録では, 在シアトル日本 領事館, 北米日本人会, キリス卜教系の教会, 仏教会, 各種実業組合ないし労働組合, 県人会, 国語・英語学校, 社交・互助・趣味・スポーツ などのクラブ，計66団体が記載されており，エ スニック・コミュニティとしての組織化が進展 したことが示される(第 8 表)。これら施設の大 部分はイェスラー道とジャクソン通り，第四街 と第八街の間の日本人町中央部に立地していた が，その東側の第十二街付近にも若干の集積が 認められた（第 5 図）。すなわち，この時点にお いても，日系コミュニティ施設の集中する地域 は営業施設の集中地域とほぼ重なり，また日系 人居住地域の主要部にもあたっていたと言える。 1928年時点には, 組織・団体数が合計111に も及び，特に経済的組織や各種社会的組織など が強化されたことが分かる(第 8 表)。

3）第 3 期 $(1930 \sim 1942)$

1936年の住所録では，合計128団体が記載さ

第 8 表 日系組織・団体数

\begin{tabular}{l|r|r|r|r|r|r|r|r}
\hline & \multicolumn{4}{|c|}{ シアトル市 } & \multicolumn{4}{|c}{ シアトル地区 } \\
\cline { 2 - 9 } & 1916 & 1928 & 1936 & 1949 & 1967 & 1973 & 1983 & 1991 \\
\hline 政治-社会的組織 & 2 & 3 & 6 & 2 & 5 & 4 & 5 & 6 \\
経済的組織 & $12^{2}$ & 23 & 22 & 1 & 8 & 7 & 4 & 3 \\
県人会・県海外協会 & 24 & 30 & 21 & - & 25 & 25 & 16 & $1^{4)}$ \\
キリスト教系教会 & 6 & 6 & 7 & 10 & 9 & 9 & 9 & 7 \\
仏教・神道系教会 & 1 & 3 & 9 & 4 & 9 & 9 & 12 & 7 \\
学校・小监園 & 4 & $15^{32}$ & $19^{3)}$ & - & - & - & 3 & 2 \\
福祉・社会サービス組織 & - & - & - & 4 & 3 & 3 & 6 & 4 \\
その他1 & 17 & 31 & 44 & - & 49 & 62 & 72 & 35 \\
\hline 計 & 66 & 111 & 128 & $21^{5)}$ & 108 & 119 & 127 & $65^{6)}$ \\
\hline
\end{tabular}

資料：各年次の日系人住所録（本文及び第 $1 \sim 7$ 表参照）

一: 資料に記載なし

1）社交・互助・趣味・演芸・スポーツなどの団体・クラブ・教習所など。

2) 労働組合 2 を含む。

3）教会付属の日曜学校等を含む。

4）実際には, いくつかの県人クラブ的組織が残っている。

5）他に種別不明の組織 1 。

6）他に系統不明の教会 1 。

81）創立年次は，前掲80）シアトル日本人基督教会同盟，前揭34）竹内，pp. 449 463，及び，在米日本人会『在米日本人 史』(発行: 著者と同), 1940, pp. 390 392, p. 410，による。

82）前掲34）竹内, p. 47, 前掲81）在米日本人会, p. 974 .

83）例えば, 誠友会 (1903), 甲辰会 (1903), ユー・シー俱楽部（1907），アジア俱楽部（1907），シアトル日本人青年俱楽 部 (1907) など。前掲81) 在米日本人会, p. 1012. 


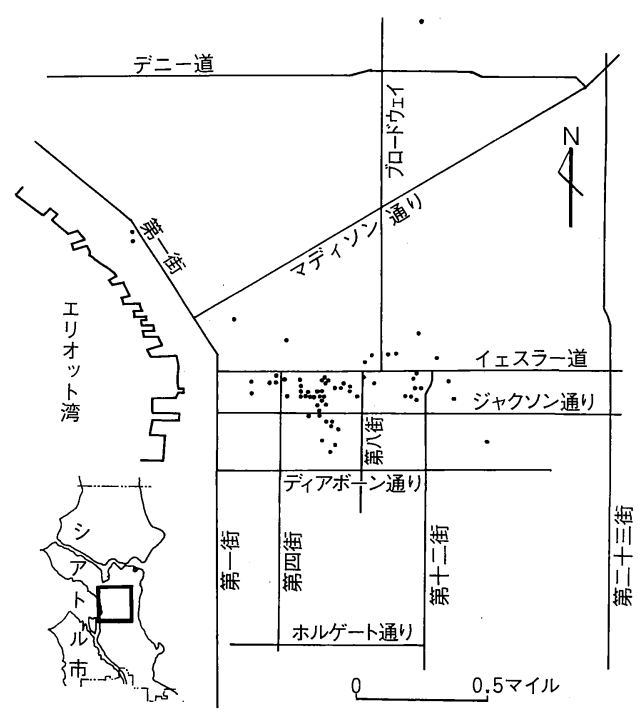

第 5 図 日系コミュニティ施設の分布（1916年） 資料 : 第 2 図と同

れており，経済的組織や県人会は停滞あるいは 減少したものの，政治的組織，宗教的組織（特 に仏教・神道系)，社会一文化的組織が拡充し， 多様化した状況が示される（第 8 表）。すなわち， この時期，日系コミュニティは「排日移民法」 下で新規流入者が事実上途絶え, 政治的・経済 的には閉塞的な状況にあったが，社会的・文化 的にはエスニックな組織化が一層進み，コミュ ニティの紐帯を強めることによって, 不利な状 況に対応していた状況が推測される。同年次の 諸施設の分布を見ると，日系人の居住地区の拡 大を反映して，分布範囲が広がってはいるが， 基本的に日本人町の中心部に主要な集積，その 東側の日系人主要居住地区にやや分散した集積 を見せている(第6図)。すなわち，同年の営業 施設に見られるような市中心部全体への進出傾 向はあまり見られず，旧来の分布核を比較的維 持していたと言えよう。

4）第 4 期（1945 1955)

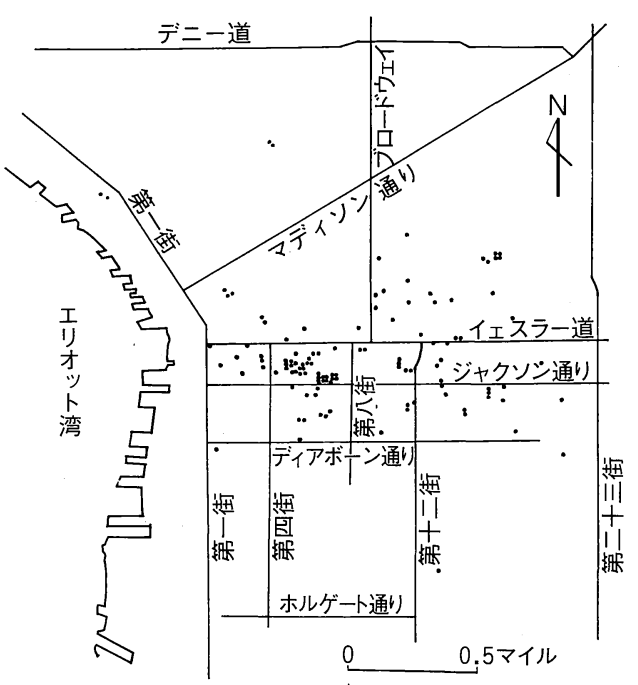

第 6 図 日系コミュニティ施設の分布（1936年） 資料：第 3 図と同。範囲 : 第 5 図と同

戦後，いち早く活動を再開したのは宗教的組 織であり，市内のキリスト教系や仏教系の教会 は，帰還した日系人達に臨時の宿所を提供する など，復興期のコミュニティの中核として機能 した。1949年の住所録では, キリスト教系の教 会10，仏教・神道系教会 4 が記載されている。 しかし，その他の組織・団体は若干を数えるの みであり，多面的なコミュニティ活動の復興は まだまだ不十分な状態にあった (以上, 第 8 表)。 5）第 5 期 (1955 )

1960年代以降，シアトルの日系社会も戦後の 再隆盛期を迎え, 政治, 経済, 社会, 宗教・文 化の各側面においてコミュニティ機能が盛んに なり, 組織の数も戦前の盛時の水準にまで回復 した（以下，第 8 表）。特に目立つのは，社交・ 互助・趣味的なボランタリー組織で, 生花, 茶 道, 日本舞踊などの日本的な趣味, 芸能の団体 も各種組織されたことは，戦後の二世中心の日 系コミュニティの社会生活の充実と文化的伝統

84）前掲80）シアトル日本人基督教会同盟，及び各日系教会での聴取による。

85）第 8 表の1949年の資料には県人会の記載がないが，伊藤によれば1947年までに少なくとも3つの県人会，さらにあまり 経ずして 5 つの県人会が復活したということである。前掲72)。 
の再生を物語っている。しかし，91年現在では， これら社交・互助・文化的な組織の数は大きく 減り, 教会もいくつか姿を消して, 全体の組織 数が半減した。これは，基本的には三世が中心 的な役割を担うようになってきた1980年代後半 に至って, 日系というエスニックな結び付きの 重要さが減じてきたことの一つの現われとも考 えられる。しかしながら, 日系人会, JACL, 二世ベテランズ・リーグ, 諸教会など主要な組 織・団体は，メンバー数の伸び恼みなど問題は かかえつつも，なお活発な活動を展開している。 これには, 古くからの二世やコミュニティ活動 に関心を寄せる三世の他に,「帰米二世」,「新 一世」, 長期在留日本人など日本語を第一言語 とする人々の役割も見逃せない。

コミュニティ施設の1983年の分布を見ると (第 7 図), 日系人人口の郊外分散を反映して, 全体の 3 分の 1 強の施設が図の範囲外に立地し ており, 全体的に分散・郊外化の傾向は否定で きないが，注目すべきことは旧日本人町域とそ の東側の地区にかなりの集積を残していること で, 営業施設に比すると分散の度合が低いと言 える。この集積地域には, 日系人会の本部や仏 教系・キリス卜教系の各教会など主要な施設が 多く，心情的（またはシンボリック）にも空間行 動の上でも，この地域がシアトル地区の日系人 コミュニティのある種の中心地区としてなお機 能していると言える。

\section{III. 結び——日系エスニック・テリトリーの}

\section{構造とその変容—}

本章では, 以上の結果を要約・総合しつつ, 各時期に抢ける日系人コミュニティの空間的展 開の特色を整理し,さらにエスニック・タウン (日本人町) の形成・成熟・衰退に焦点をあてて, 当該都市における日系エスニック・テリトリー の構造とその変容及びその意味するところを考 察して, 結びとする。

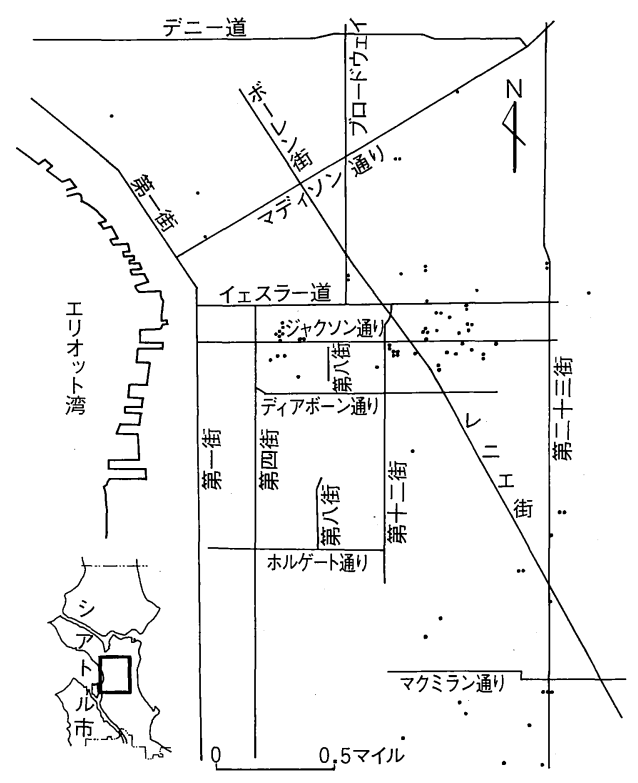

第 7図 日系コミュニティ施設の分布（1983年） 資料：第 4 図（第 6 表）と同

第 1 期 ( 1907): この時期, 単身出稼ぎ者を 中心とした日系人達はダウンタウンの南縁, 海 岸寄りのいわゆるスキッドロード地区にきわめ て限定的に居住していた。また，ほぼ同じ地域 で, 少数のビジネス・パイオニア達がホスト社 会指向型の飲食店や雑貨店などを経営していた。 社会的には全体的に未組織で, コミュニテイ施 設はまだほとんどなかった。しかし，この時期 の末（1900年頃以降）になると, 居住や営業活 動が少し山手寄りの地区に移り始め, そこに初 期の教会なども建てられて，萌芽的なエスニッ ク・タウンが出現し始めた。

第 2 期 (1907 1930): この時期, 日系社会で は家族の形成が進行し, 定住傾向が一層強まり, 社会的組織化と職業的分化をもつエスニック・ コミュニティが確立した。主たる居住域はファ ーストヒルの南西斜面であり, 若干の居住分散 はあるものの大部分の日系人口は比較的狭い地 区に密集していた。日系の商業・業務施設は, $7 \sim 8$ 割がこの密集居住地域の中に立地し, 特 にその西半分には繁華な商業・業務街が形成さ 
れた。また，諸コミュニティ施設も，ほとんど がこの区域内に建てられた。このように，第 2 期は，エスニック・テリトリーの範囲が比較的 限定され，その中に密集居住，ビジネス活動， コミュニティ活動が空間的に重なり合う典型的 な日系エスニック・タウン (日本人町) が出現 した時期と言える。

第 3 期（1930～1942）：この時期は，「排日移民 法」下で新規参入者が途絶え，人口面での減少 など閉塞的な状況に苦しみつつも，二世世代の 割合が確実に増加し，いろいろな面でコミュニ ティの成熟も見られた時期と言えよう。日系人 の居住分布は基本的に前の時期の集住パターン を踏襲していたが，主要居住地区の東方への拡 大，中心部での密度低下，南方ビーコンヒル方 面への拡大などの変化も現れてきた。市内の日 系営業施設数はさらに増加し, ビジネス活動の 多様化が見られたが，日本人町域のシェアーは 低くなり，全体に都心おょびその周辺地区全体 への分散傾向が出てきた。また，日系の組織・ 団体は多様化し, その数も増加したが, その施 設の分布は営業施設ほど分散せず，旧来の分布 核を比較的維持する傾向を示していた。このよ うに，この時期，エスニック・テリトリーはや や拡大・分散化を示したが，その核となるエス ニック・タウンは基本的に維持された。

第 4 期（1945～1955）:この時期は, 戦時の強 制立ち退きによって中断したコミュニティの回 復期・再形成期にあたる。居住分布の上では, 戦前に比較的近い形で集住パターンが再現され, 外方への分散は限られていた。ビジネス活動も 1950年頃までにはある程度回復し，ほぼもとの 日本人町の位置に縮小された形の日系商業・業 務地区が再興された。社会的活動では教会がも との位置を拠点にいち早く活動を再開したが,
他の組織・団体の復興ははかばかしくなかった。 このように, この時期全体として戦前のエスニ ック・テリトリーの構造に近い形が再形成され, エスニック・タウンも復興していったが, 十分 に回復しないうちに次のステージを迎える。

第 5 期 $(1955 \sim)$ : この時期，シアトルの日系 人コミュニティは, 二世さらに三世がその主要 な担い手となる時代を迎え，様々な面で大きく 変容していく。戦前の水準を越えて増大した日 系人人口は, 古くからの居住地区にもある程度 の集積は残したものの，その南方のビーコンヒ ルやレニエヴァレー方面を中心にその分布域を 拡大し, さらに70年, 80 年代にはシアトル大都 市地域全体に広く分散・郊外化した。ビジネス 活動も，ホテル・アパート業 (前半) や専門的 サービス業 (後半) などを中心に再び隆盛を見 たが, その立地パターンは大きく変化し, 全体 としてシアトル市内, さらに大都市地域に分散 ・郊外化した。この過程で, 旧日本人町域のビ ジネス集積は縮小・解体していったが，なお現 在数の上で10\%程のシェアーを保っている。コ ミュニティ活動も人口の分散につれ必然的に広 域化したが，主要な組織・団体の本部・施設は 比較的もとの位置あるいはその近くに残存する 傾向を示し，ある程度中心的な集積を残してき た。このように, この時期, 基本的に日系エス ニック・テリトリーは広域化・郊外化し，その 構造も変化したが, 旧中心地区の役割は完全に は消失せず，特に社会的・心理的な面で核（コ アー）の機能を維持してきたと言えよう。

以上, 各時期の特色を整理してみたが, 最後 にこうした一つのエスニック集団の空間的展 開を規定し，エスニック・テリトリーの構造の 変化を引き起こす背景や要因についてなるべく アメリカ合衆国における日系人史の特殊性を捨

86）周知のように，アメリカに移住した「日本人移民」は，基本的に市民権取得を認められない「帰化不能外人」であり， 社会的・制度的な様々な差別・排斥の末, ついに第 2 次大戦中には, その主要な居住地域である西海岸からの強制的立ち 退き・収容という他のエスニック・グループが経験しなかった歴史を強いられた。 
象しつつ，考察してみよう。

エスニック・グループの空間的状況，あるい はそのテリトリーの空間構造は，その集団自体 の社会・経済・文化的特性及びその集団を取り まくホスト社会との関係, 換言すれば広い意味 でのエスニシティ，と密接な相互規定関係をも つと考えられる。まず，空間的状況がエスニシ ティによって規定され, その結果として生産さ れてくる側面について考えてみよう。

シアトルの日系人コミュニティのテリトリー は, 特殊な時期を除いて基本的に外延的拡大を 続けてきたが，これは当該エスニック集団の人 口増加とホスト社会の受容 (accommodation) の 結果としてとらえられる。この基本的動向の中 で, 集中居住域を維持し，その中で商業・業務 地区と社会的活動核を生み出す動き，すなわち エスニック・タウンという特色ある社会空間を 形成する現象，はマジョリティ社会のマイノリ ティを空間的に閉じ込めようとする差別・排斥 の力も無視できない要因ではあるが，それ以上 に当該集団の文化的・社会的アイデンティティ を保持し，内的統合を保とうとする移民エスニ ック集団にとっての必然的な性向の結果と言え る。このようにして形成されたエスニック・タ ウンがその集団にとって否定的な意味のみでの 「ゲットー」や「スラム」とはかなり質的に異 なる゙ ことは言うまでもない。しかし，この傾向 も, シアトルの日系人の場合, 1950年代半ば頃 までで，それ以降になると，エスニック・テリ トリーが急速に拡大・分散化し，その中でそれ まで中核的な役割を果たしてきたエスニック・ タウン, 特にその商業・業務核が縮小・解体に 向った。これは一世世代，あるいはその影響を 強く受けた古い二世世代がコミュニティの中核
から退き，代ってマジョリティ社会への構造的 同化が進んだ三世世代の力がコミュニティの中 で大きくなるにつれ，エスニック・テリトリー の求心的構造を支えていた内的なエスニックな 力と外的な制約が弱まった結果として理解され る。

一方，空間的構造や具体的に形成された都市 地域の諸状況は，そこに生きる人々の行動や社 会一心理的状況を制約する力を有し，それが空 間構造自体にフィードバックする。また，空間 的構造はそれ自体存続しようとするある種の慣 性や復元力をもつ。上述の第 1 ～ 3 期のシアト ル日系人コミュニティにおいては，限定された 空間的範囲に集住することによって，人々は対 面的なコミュニティを形成し，その内的結合力 を維持することが容易であった。また，外的な カによって中断を強いられたエスニック・タウ ンが第 4 期にほぼ同じ位置に復興してくる現象 には，空間的構造のもつ惰性や復元力が働いて いると見ることもできる。さらに，第 5 期では 空間的に拡大したテリトリーの形態自体がコミ ュニティの結合力と求心力を弱める要因として 働き，それがさらに次のステップのテリトリー の拡大・分散につながっていったと考えられる。

しかし, こうした基本的動向の中にあって, エスニック集団としての日系人のエスニシティ が消滅し, そのテリトリーの構造も完全な解体 に向っていると結論することは正しくない。前 述したように，シアトルの日系人エスニック・ テリトリーの中核にはなお社会的活動核が残存 しており，その活動も決して衰えてしまったと は言えないのは何故であろうか。これについて も，そうした現象を支えるコミュニティやそれ を取りまく社会の性質及びその拠点となるコミ

87）第 2 次大戦中の強制収容時やその後の再定住期（第 4 期）などを指す。

88）ちなみに, ウールストンは，1920年代におけるシアトルの日系人集中地区の生活環境を調査し，住居は貧弱ながらも清 潔でよく手入れされており, 子供は従順で学力も平均かそれ以上, 世帯は標準生活を送るのに十分な収入をもっていたこ とを明らかにしている。Woolston, K. D., Japanese Standard of Living in Seattle, MA Thesis, Univ. of Washington, 1927, 31p. 
ユニティ施設自体とそれを取りまく環境の空間 的性質の両面から考えていくことが求められる。 すなわち, 前者については, コミュニティの社 会的活動を支える人々の中には，退職年齢は越 えてはいるもののなおコミュニティの中では活 発な二世，構造的そして文化的にも同化・アメ リカ化が進んではいるが，そのアイデンティテ イの一部を日系ないしアジア系のつながりに求 める三世，そして日本語が第一言語である帰米 二世，新一世，長期在留日本人など多様な人々 が含まれていることに留意しなければならない。 また，アメリカ合衆国の場合，エスニック・コ ミュニティを取りまく社会も，文化的多元主義 を基調としたものに変ってきており，文化的・ 社会的次元でのエスニシティの再活性化には, 少くとも不寛容ではない。後者については，コ ミュニテイ施設自体が今日日常の接近性よりも 拠点としての安定性, シンボル性を求める性質 をもっていること，モータリゼーションの進展 がコミュニティ成員の広沉な空間的凝集を可能 にしていること，などを挙げることができる。 いずれにしても，移民エスニック集団のエスニ シティは，長期的には同化による解体の方向に 向かうとしても，新しい社会のコンテキストの 下では常に新しい相が再生産され，それがエス ニック・テリトリーの集心性をある程度長い期 間維持してきたと見ることができる。

以上，述べてきたシアトルの日系人コミュニ ニティを例とした考察が，北アメリカの都市の 移民エスニック・テリトリーの構造とその変化
の一般的傾向に，どの程度適用し得るかについ ては，現段階で十分なことを言うことはできな い。しかし，エスニック・テリトリーのダイナ ミックな変容を考えるためにはエスニック・ビ ジネスの展開とエスニックな社会的組織化の側 面が不可欠であること，そしてテリトリーのコ アーであるエスニック・ゲットーのあまりにも 否定的かつステレオタイプ的見方や，そこから の脱出，郊外化を集団成員の経済的余裕にのみ 求める単純な“エレベーター・モデル”のみで は当該問題の考察にはきわめて不十分であるこ と，などは示し得たと思う。

本研究の遂行にあたり, 元ワシントン大学地理 学教室の George H. Kakiuchi 先生には，終始暖 かいご支援と貴重なご助言を賜った。また，同大 学アジア系アメリカ人研究所 Tetsuden Kashima 先生, 同大学名誉教授 Frank S. Miyamoto 先生, 北米報知新聞社編集局長楠瀬明子氏には，様々な ご教示と資料の提供をいただいた。その他，一々 㧍名前を記し得ないが，シアトルの日系コミュニ ティの実に多くの方々に，ご協力いただいた。な お, 本研究の調査の一部は, 平成元年度文部省科 学研究費補助金 (国際学術研究) 及び平成 5 年度 同研究の一環として行ったものである。研究代表 者の高津斌彰氏 (新潟大学) を始め, 研究参加者 の實清隆氏，阿部隆氏，水見山幸夫氏，村上雅康 氏のご協力を得た。なお，英文要旨は，Aasia Bora 氏（ロンドン在住）にご検討いただいた。 以上の方々に，心から御礼申し上げたい。なお， 本研究の概要は, 日本移民学会（1993年12月12日, 津田塾大学) 及び東北地理学会（1994年 5 月21日, 仙台市戦災復興記念館）に打いて発表し, 討議を 得た。

(岩手大学人文社会科学部)

89）アメリカのエスニック集団においては, 構造的同化とエスニシティの維持がゼロサム関係にないという見方や，さらに 文化面・アイデンティティ面におけるアメリカ化もエスニシティの活性化と矛盾する現象ではないとする議論が近年提示 されている。竹沢泰子『日系アメリカ人のエスニシティ一強制収容と補償運動による变遷一』, 東大出版会, 1994, pp. 235-244, 参照。 


\section{Settlement Processes of the Japanese and the Changing Structure of Their Ethnic Territory in Seattle}

In the studies on ethnic immigrant groups in urban areas, the patterns of ethnic residential segregation have been central to geographical concerns, and many other important aspects such as the dynamic formation processes of ethnic territories and their changing structures relating to development of ethnic businesses and social organizations have tended to be overlooked by geographers. This paper is an attempt to understand the settlement processes of an ethnic group and the changing structure of its ethnic territory in an urban area, taking the example of Japanese immigrants and their descendants in Seattle, a city on the West Coast of the United States.

In this paper, three aspects of the spatial processes of the ethnic group are considered: 1 ) population distribution, 2 ) spatial development of ethnic businesses, and 3 ) ethnic organizations and their facilities. To describe these changing aspects, the development history of the Seattle Japanese can be divided into five major stages; I (-1907), II(1907-1930), III (1930-1942), IV (1945-1955), and V (1955-).

The main information for this study is based on the documents which the author collected during his research visits to Seattle from 1989 to 1993 . From among many items, the Japanese-American directories of the years of 1916, 1928, 1936, 1949, 1967, 1973, 1983, and 1991 were examined to analyze the changing composition and distributional patterns of Japanese-owned or -managed businesses as well as their ethnic organizations and institutions. As for the changing population distribution of the Japanese, several existing studies by Miyamoto, Schmid et al., Leonetti, and Abe were helpful.

In the first stage (-1907), the Japanese in Seattle, most of whom were young or middle aged single male labor migrants, lived mainly in the so-called 'skid road' area, the south fringe of downtown. A small number of pioneering business people ran restaurants, grocery stores, or hotels, mainly for local white laborers in the same area. However, few community facilities had been established by the end of this period and Japanese society had remained as a labor migrant society rather than changing to an ethnic community.

In the second stage (1907-1930), the Japanese community in Seattle changed its character gradually over time with marriage and the coming of children as well as the establishment of social leadership and organizations, and became a true local ethnic community. Most of the Japanese in this period lived in a limited area on the south-west slope of the First Hill, and their community facilities such as churches, schools, and headquarters of various political, social, or economic organizations were located within this area. By the relatively early years of this stage, the Japanese began to run various kinds of businesses such as hotels, restaurants, groceries, barbershops, bathhouses, etc., and these commercial and business facilities were mainly concentrated in a small area of the western part of their residential core area. In this stage, a typical ethnic town of Japanese, the so-called Nihonjin-machi, or Japantown, appeared through the concentra- 
tions of their residences, business facilities, and social facilities into a small limited area in the urban region.

In the third stage (1930-1942), new arrivals of Japanese immigrants ceased practically under the so-called Anti-Japanese Immigration Act which was passed in 1924, and the Japanese community suffered from the hostile atmosphere against Japanese of the host society. However, the proportion of the second-generation Japanese who were born in the United States was increasing rapidly and Japanese society reached a new mature stage owing to that generation growing up. The residential distribution of Japanese had generally retained the cluster pattern which was formed in the former stage, but some changes took place: the expansion of the main cluster towards the east, the thinning of the population in the center of the core area, and some dispersion to Beacon Hill, a relatively new residential area south of downtown. The total number of Japanese businesses increased by the middle of the 1930's, but their distributional patterns had changed to some degree; about half of them had come to be located outside Japantown through dispersing throughout downtown and its surrounding areas. The number of their ethnic organizations increased also in total. However, their facilities had not so dispersed spatially as the business facilities, but were still relatively concentrated in and around the core residential area of Japanese.

The fourth stage (1945-1955) was the recovery period of the Seattle Japanese community after the internment of Japanese during World War II. However, before their recovery process had been completed, a time of great mobility began by the end of the 1950's.

In the fifth stage (1955-), the Japanese community in Seattle faced many drastic changes. The second and third generations came to predominate in their society. Their residences have been largely dispersed throughout the metropolitan area of Greater Seattle during the 1970's and 1980's. Japanese business activities have also dispersed spatially throughout the city of Seattle and, in part, suburbanized into other areas of Greater Seattle. In this process, the concentration of Japanese businesses in Japantown has been reduced gradually, but it has still about a 10 percent share of the total Japanese businesses in Greater Seattle. Community activities of Japanese have inevitably expanded spatially as their residences have dispersed. However, their headquarters or main facilities tend to remain in the former residential cores in and around Japantown, and this concentration of social facilities has come to serve as a symbolic focus for the expanded entire ethnic territory.

These spatial changes of an ethnic territory are closely related to the changes of the socio-cultural characteristics of an ethnic group and the situations in which it lies, in other words, the ethnicity. The causal factors for the formation and retention of the ethnic core area are considered to be the demand of the members of an ethnic group for reserving their cultural and social identities and internal cohesion as a group as well as the hostile attitude of the majority which tries to restrict their activities within a limited space. On the other hand, the spatial propinquity of the members of an ethnic group serves to strengthen their ethnicity. The spatial dispersion of their residences and businesses is usually considered to be related to their cultural and structural assimilation and accommodation into the host society. However, it is not correct to suppose an 
ethnic group would totally assimilated into a host society and come to show no more distinct territorial character in a relatively short period of two or three generations. Now, the Japanese community in Seattle faces the stage when the third generation Japanese dominate in their social and business activities, but their territory still retains its centrality to some degree through reserving their social activities core and some business concentration as mentioned above. This teaches us that ethnicity has not easily disappeared with assimilation but it may be reproduced under new contexts of such a society.

Key words : Japanese American, ethnic territory, Japantown, ethnic business, ethnic organization, Seattle 